\title{
A METHOD FOR THE EVALUATION OF THE SEISMIC CAPACITY OF EXISTING REINFORCED CONCRETE BUILDINGS IN JAPAN
}

\author{
Hiroyuki Aoyama*
}

\begin{abstract}
:
A three-level procedure for seismic capacity evaluation of existing reinforced concrete buildings, developed in Japan, is reviewed. The paper describes basic principles and their background which formed the basis of the evaluation method. The outline of the three-level procedure is given and the applications of the procedure to buildings which experienced several recent destructive earthquakes in Japan, are reviewed. A seismic protection index, to determine the appropriate level of seismic capacity, is proposed. A hypothetical four-storey frame building in New Zealand is evaluated by the three-level procedure. Subsequently comments are offered with respect to problems that may arise if the Japanese procedures were to be applied to buildings in New Zealand.
\end{abstract}

\section{INTRODUCTION:}

Rapid growth in the art of design for earthquake resistance has enabled new buildings to be designed with improved prospects of satisfactory behaviour during earthquakes. At the same time, innovations in seismic design methods have left some doubts in the adequacy of seismic behaviour of existing buildings. In addition to very old existing buildings for which seismic design was not considered, the behaviour of thousands of Japanese buildings, designed according to old building codes, is questioned whenever a revision is enforced to meet more stringent requirements. Fortunately not all existing buildings would prove to be inadequate, owing to sound engineering design which always left some margin of safety above the required minimum level. However, this cannot be taken for granted. It is possible, in any urban area with engineered buildings, that a certain portion of existing buildings is in fact inadequate in the light of improved seismic design standards.

In Japan, this type of problem became apparent in a broad scale for the first time after the 1968 Tokachioki earthquake, which caused more than moderate damage to about fifteen percent of code-designed reinforced concrete buildings in the afflicted area. In addition to efforts toward the revised building code and design standards, several methods were developed for the evaluation of seismic resistance of existing buildings $(1,2,3,4)$.

In observing the damage caused by the 1968 earthquake, it was apparent that the amount of shear walls used played the most important role. This was also the case in previous earthquakes. A quantitative evaluation by $\operatorname{Shiga}(5,6)$ which will be discussed later in this report, provided convincing evidence. As to frame buildings or frame portions of buildings, shear failure of columns was the most prevalent type of serious damage

\footnotetext{
*Professor, Department of Architecture, University of Tokyo, Japan. (Visiting Professor, University of Canterbury, 1980).
}

or even failure. Conversely, sufficient shear capacity was apparently the most effective way to provide ductility in many structures.

Seismic safety of existing buildings was particularly of serious concern to the agency in charge of the administration of a large number of buildings, for example the Ministry of Construction, responsible for all government-owned buildings, and the Ministry of Education, responsible for all school buildings. When earthquakes affect some other parts of Japan with a similar intensity as that of the 1968 event, a similar proportion of existing buildings would suffer a similar extent of damage, because practically all Japanese buildings have been designed for the same building code requirement. Hence a basic motive in evaluation methods was to detect which of the large number of existing buildings would be more likely to be damaged. The operation is often referred to in Japan as "screening" or "sifting".

As attempts of evaluation became more relevant the need for a nation-wide evaluation of existing buildings was recognized. In 1977, a unified "Standard for Seismic Capacity Evaluation of Existing Reinforced concrete Buildings" was compiled under the guifance of the Ministry of Construction (7). It was a timely. achievement, for the seismologists' prediction of a magnitude 8 earthquake in this century in the Tokai area (including the Shizuoka Prefecture) created an even greater demand for the assessment of seismic behaviour in the following years.

In this report, the outline of the "Standard", together with some background information (8), is described, and its application to Japanese buildings is introduced. A proposal for the seismic protection index is also shown. An application to a hypothetical New Zealand building illustrates the procedure numerically. This is followed by some discussions of the results.

2. BASIC PRINCIPLES OF THE EVALUATION 


\subsection{General}

Modern buildings in Japan are designed for earthquakes according to the building code which specifies a consistent magnitude of lateral design force for a particular type of building. The real capacity of a building structure is generally larger than the code-specified lateral force. It appears that there is a smaller difference between the real and code-specified "lateral strength" in the case of frame buildings than in the case of shear wall buildings, as the capacity of frame structures can generally be more accurately assessed than shear walls. In the case of low-rise buildings of limited ductility, where shear walls, often squat, play a more important role in seismic resistance, differences can be quite significant. Due mostly to structural planning and the interaction with architectural (nonstructural) elements, some buildings may have a seismic capacity barely exceeding the code-specified strength, while the capacity of others may well exceed the specified value by the factor of 3 or 4 or even more. An evaluation of real strength of low-rise reinforced concrete buildings in Japan has recently been published in New Zealand $(6)$.

Figure 1 shows qualitatively lateral load-deflection relationships. Stronger buildings are usually stiffer and less deformable. As is well known earthquake resistance is not a function of lateral strength only. Structures with different strengths can be designed satisfactorily for earthquake resistance if an appropriate amount of deformability - or ductility is assured. A building with a Type I' response as shown in Fig. I may be stronger than a building with a type III response. However, it will be much more vulnerable to earthquake attack. Thus the seismic performance evaluation of existing buildings must involve both strength and deformability.

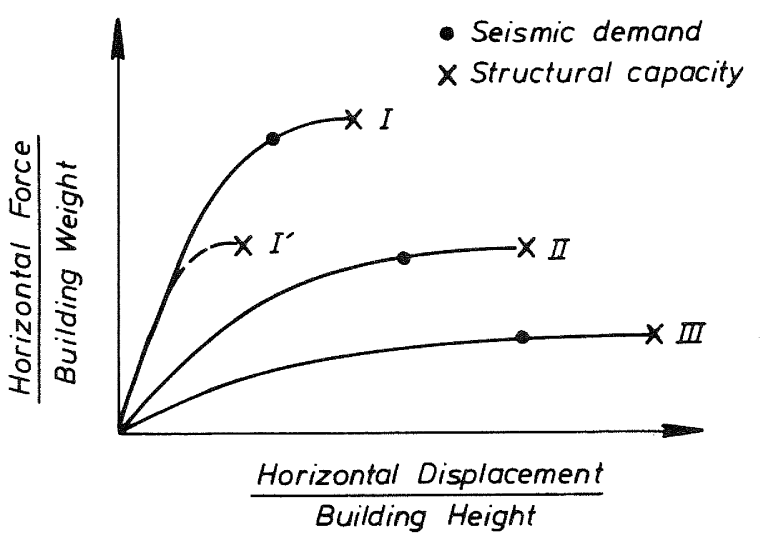

Figure 1 - Strength and Deformability

This situation is common in analysis and design and evaluation of structures. What makes the evaluation distinctly different from the analysis and design, is shown if Table 1 , compiled originally by okada $(9)$. In structural analysis generally external disturbances such as lateral force or earthquake induced motions are given, structural papameters such as stiffness or strength are assumed or are given, and at the end structural response, generally in terms of deformation, is to be found. Structural design involves the determination of all the details of the structure subjected to the given external disturbances and satisfying the given design criteria which may be interpreted in terms of deformations. Structural evaluation is different because the structural details are all known, hence the strength is given, and the deformation capacity is also given. What is to be found is the intensity of external disturbance under which the structural response would reach the deformation capacity.

TABLE 1 - ANALYSIS, DESIGN AND EVALUATION OF STRUCTURES

\begin{tabular}{|l|c|c|c|}
\hline & Analysis & Design & Evaluation \\
\hline $\begin{array}{c}\text { Earthquake } \\
\text { Force or max. } \\
\text { acceleration) }\end{array}$ & GIVEN & GIVEN & TO BE FOUND \\
\hline $\begin{array}{l}\text { Strength } \\
\text { (Yield Load) }\end{array}$ & GIVEN & $\begin{array}{l}\text { TO BE } \\
\text { FOUND }\end{array}$ & GIVEN \\
\hline $\begin{array}{l}\text { Deformation } \\
\text { (Ductility) }\end{array}$ & $\begin{array}{l}\text { TO BE } \\
\text { FOUND }\end{array}$ & GIVEN & GIVEN \\
\hline
\end{tabular}

\subsection{Basic Seismic Index}

The basic seismic index $E_{0}$ in the "Standard for Seismic Capacity Evaluation" is defined as follows:

$$
\mathrm{E}_{\mathrm{O}}=\phi \mathrm{CF}
$$

where

$$
\begin{aligned}
& \phi=\text { storey index } \\
& C=\text { strength index } \\
& F=\text { ductility index }
\end{aligned}
$$

This equation postulates that the seismic capacity of a storey may be evaluated from the product of strength index and the ductility index, modified by a storey index. The latter relates the singledegree-of-freedom response to that of multistorey structures. When a storey consists of groups of vertical members having different deformation characteristics, the expression for $\mathrm{E}_{\mathrm{O}}$ becomes more complicated than Eq. (1). For the time being it will be assumed that a storey consists of members having similar deformation characteristics. The storey shear divided by the total weight of the building above, to give the appropriate storey shear coefficient, is the strength index $\mathrm{C}$ in $\mathrm{Eq}$. (1).

$F$, the ductility index, is a function of the ductility factor. For a perfectly 
elasto-plastic system, shown in Fig. 2, it is well known

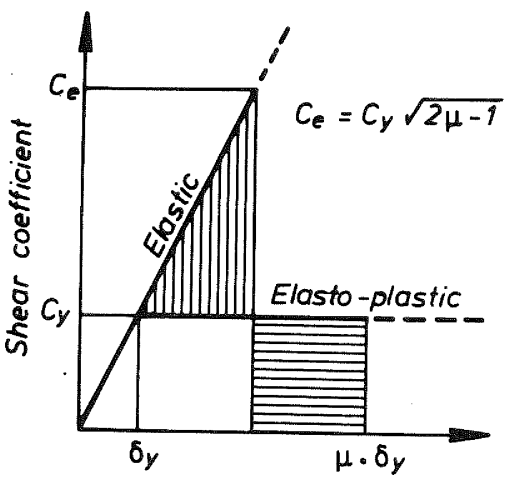

Displacement
Figure 2 - Elastic and Elasto-plastic

that Newmark's equal energy criterion leads to a good approximation of inelastic response of medium and low-rise buildings. As shown in Fig. 2, by equating the appropriate areas, the criterion can be expressed as follows:

$$
c_{e}=c_{y} \sqrt{2 \mu-1}
$$

where $\mathrm{C}_{\mathrm{e}}=\begin{aligned} & \text { ratio of elastic response } \\ & \text { acceleration to gravity }\end{aligned}$ acceleration

$$
\begin{aligned}
& c_{y}=\text { yield shear coefficient } \\
& \mu=\text { response ductility factor }
\end{aligned}
$$

In this case $F$ may be made equal to $\sqrt{2 \mu-1}$.

As the hysteretic behaviour of reinforced concrete structures differs considerably from that of the perfect elasto-plastic model, a number of different nonlinear models were devised. Also a considerable amount of nonlinear analysis has been carried out. Among them, the "Standard" adopted the following modification to Newmark's expression i.e. Eq. (2).

Fig. 3 shows a degrading trilinear model. This is believed to be a good representation of reinforced concrete hysteretic response for gpmponents failing primarily in flexure $(8,10)$. Up to yielding, the model is similar to the bilinear model with a stiffness change at the cracking point. Once deformation exceeds the yield point, the model assumes a perfectly plastic system. Upon unloading, the unloading point is treated as a new "yield" point in the next cycle of loading in the same direction, and the unloading stiffnesses, corresponding to pre- and post-cracking stages, are reduced proportionately, so that the behaviour is of a bilinear type in the range between the positive and negative "yield" points. The equivalent damping factor, an index for hysteretic energy dissipation, becomes constant in the post-yielding range. For this reason, the cracking point in the initial range is selected so as to provide

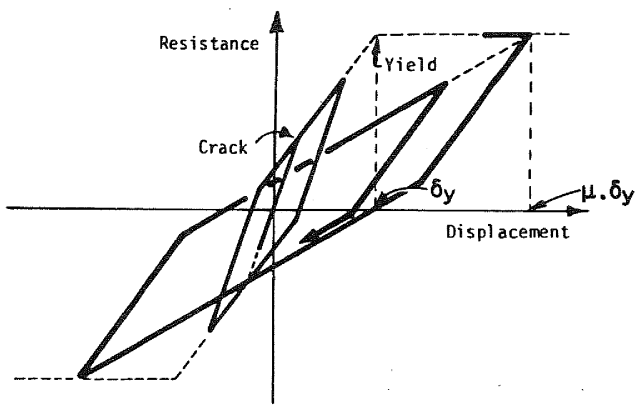

Figure 3 - Degrading Trilinear Hysteresis Model

a reasonable equivalent damping factor, rather than representing the crack strength.

Fig. 4 is an example of the displacement response spectra for the 1968 Hachinohe earthquake of degrading trilinear single-degree-of-freedom models having different strength levels(11). In Fig. 4 $\mathrm{F}_{\mathrm{y}}=\begin{aligned} & \text { yield strength with respect to } \\ & \text { lateral load }\end{aligned}$

$\mathrm{m}$ = mass of building

$a_{0}=$ peak ground acceleration taken here as $1.0 \mathrm{~g}$

$\beta=$ fraction of critical damping

$\mathrm{F}_{\mathrm{cr}}=$ strength developed at cracking

$\alpha_{y}=$ ratio of secant stiffness with reference to first yield and first cracking respectively.

For the range of period greater than about $0.8 \mathrm{sec}$, the maximum inelastic response displacement is approximately the same as elastic response displacement. For shorter period structures the maximum inelastic response displacement is generally greater than that of the elastic response, and this is more pronounced for shorter periods and for decreased yield strength, $\mathrm{F}_{\mathrm{Y}}$.

The ratios of yield shear coefficient, $c_{y}$, to the elastic response shear coefficient, $\mathrm{c}_{e}$, and resulting ductility demands, $\mu$, from four recorded earthquake motions are plotted in Fig. 5. Here the elastic response is approximated by a constant acceleration, which is taken to be 3.33 times the maximum ground acceleration. When the computed ductility demands are compared with a curve corresponding to Eq. (2), it is seen that these are smaller in the higher strength zone, and could be larger in the lower strength zone, than the prediction from Eq. (2). The definition of ductility used in this study is based on the yield displacement shown in Fig. 3. In the case of the results given in Fig. 5, the ductility is derived from the secant stiffness taken as $\frac{1}{2}$ or $\frac{1}{4}$ of the elastic stiffness. This accounts for the differences in the high strength range. The tremendous increase of 


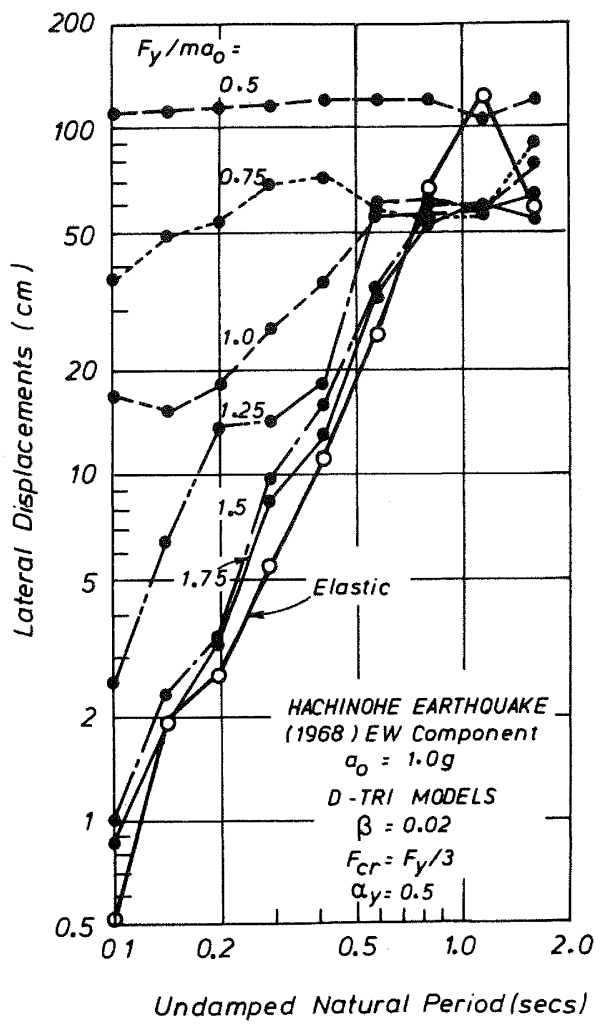

Figure 4 - Displacement Response Spectra of Degrading Trilinear SDF Systems

inelastic response displacements in low strength structures shown in Fig. 4 results in the wide range of ductility demands for low strength structures of Fig. 5 .

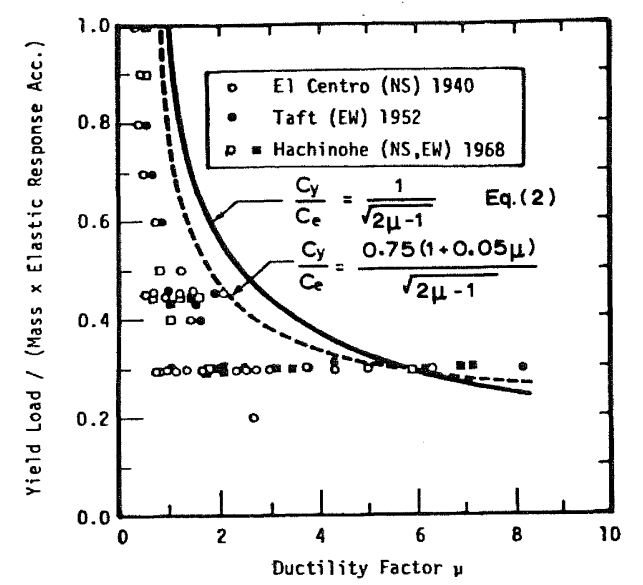

Figure 5 - Yield Strength and Resulting Ductility Demand for Degrading Trilinear Models

An empirical expression to approximate the upper bound of the computed response was proposed as follows,

$\frac{c_{y}}{c_{e}}=\frac{0.75(1+0.05 \mu)}{\sqrt{2 \mu-1}}$ where $C_{e}, c_{y}$ and $\mu$ are as defined earlier. This expression is taken to be valid only when the ductility demand is not more than 5 . For a given strength $\mathrm{C}_{\mathrm{y}}$, and an available ductility capacity, $\mu$, this expression gives the maximum elastic response, $c_{e}$, for which the ductility demand during the nonlinear response will not exceed the ductility capacity. Hence, the ductility index, $F$, is expressed as

$F=\frac{\sqrt{2 \mu-1}}{0.75(1+0.05 \mu)}$

The storey index $\phi$ in Eq. (1) may be defined as

$\phi=S D F$ response/storey shear $=C_{e} / C_{i}$

For an idealized elastic structure of $n$ degrees of freedom, having uniform mass distribution and storey heights, and having a linear mode shape, storey shear coefficient of $i-t h$ storey, $c_{i}$, may be obtained as

$c_{i}=\frac{3(n+i)}{2(2 n+1)} c_{e}$

Hence, the story index is defined as

$\phi=\frac{2(2 n+1)}{3(n+i)}$

This expression may be used when the abovementioned assumptions are reasonably true; in particular, when the fundamental mode shape is reasonably close to a straight line, both in the elastic and inelastic ranges. Structures with weak beam-strong column frames, or with flexural or rocking shear walls, are suitable for the use of Eq. (6). A modified definition of storey index,

$\phi=$ base shear/storey shear

leads to a more conservative expression

$\phi=\frac{n+1}{n+i}$

The use of this expression is recommended by the Standard for types of structure that do not meet the assumption relevant to the linear mode shape.

\subsection{Combination of Seismic Indices}

Many structures may consist of more than two lateral load carrying systems. These may fail at different displacements. On the basis of Japanese observations the load-deformation relationship of vertical reinforced concrete members may be idealized as shown in Fig. 6, where

$\alpha_{i}=$ reduction factor allowing for deformation compatability.

For example from Fig. 6 the load carried by a ductile column at a deformation angle of $1 / 500$, the maximum for a short column, is $\alpha_{3}$ times its full capacity.

The critical member rotation angle, defined as the critical lateral relative end displacements divided by member length, is defined for various members as follows: 
(a) At a shear failure in short columns

(b) At a shear failure in walls

$1 / 250$

(c) At flexural yielding of walls 1/250

(d) Flexural yielding of columns $1 / 150$

These quantities are approximate values based on the observed deformations of components in existing buildings.

If a storey is idealized as a series of vertical members such as in Fig. 7, the load deflection relationship for the entire storey under the monotonic loading could be represented by the curves in Fig. 8. When stiff, strong but brittle members fail during an earthquake, the response may be significantly affected by the sudden loss of resistance. If the strength of brittle members is relatively high, as in Fig. 8(a), the failure of the brittle member might result in the failure of the structure. In this case the remaining ductile system may be too weak to withstand the remaining earthquake motions. On the other hand, if the strength of brittle members is moderate, as in Fig. 8(b), some earthquake energy will be dissipated by the brittle members before failure. Thus, it may be expected that the remaining reduced earthquake motions will remain within the capacity of the ductile member. Therefore, the displacement response of this structure must be smaller than that of a structure consisting of the ductile members alone.

The response of two parallel inelastic systems was studied (12). In this the stiffness properties of a brittle system (walls) were represented by an origin-oriented model (a model having progressive stiffness degradation but possessing no ability for hysteretic energy dissipation), and those of a ductile system by a degrading trilinear model. The two models were connected in parallel, thus being subject to common displacements and having also a common mass. The origin-oriented model was assumed to fail when the displacement reached twice its yield displacement, and no resistance was assumed for greater displacements.

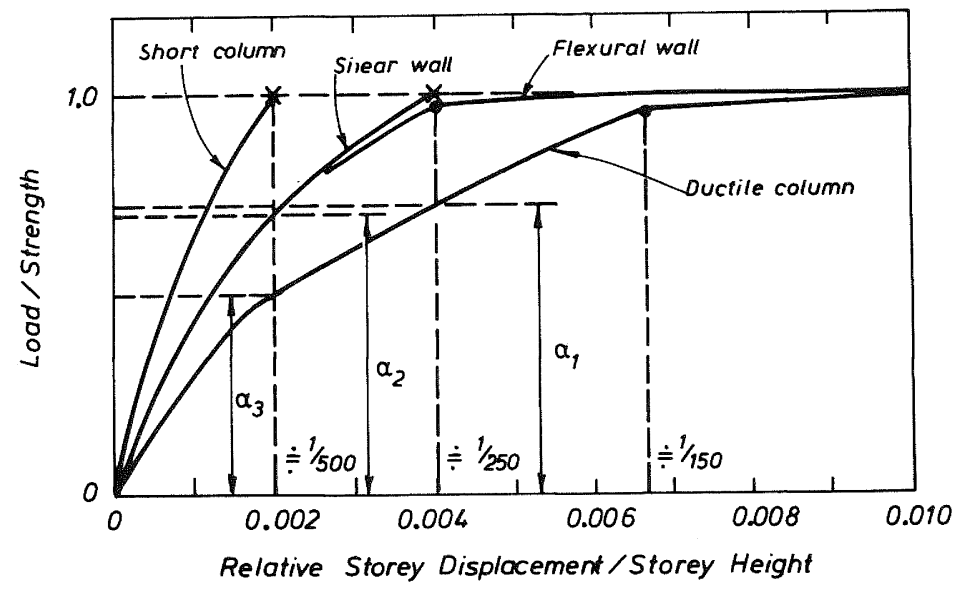

Figure 6 - Idealized Load-Deformation Relationship
The strengths of a degrading trilinear model (frame) and an origin-oriented model (wall), resulting in the same maximum displacement response during the 1952 Taft earthquake input, are plotted in Fig. 9. The strengths were defined as the yield resistance of the system divided by the common weight. For design purposes the contour line may be approximated by an ellipse when frame ductility is greater than 2. When frame ductility becomes less than 2, the contour line approaches a straight line.

Thus for a building consisting of one brittle and one ductile vertical element each having basic seismic index of $E_{1}$ and $E_{2}$, such that

$E_{1}=\phi C_{1} F_{1}$

(wa11)

$E_{2}=\phi C_{2} F_{2}$

(frame)

two kinds of combination may be used. one is a linear combination

$\mathrm{E}_{\mathrm{O}}=\phi\left(\mathrm{C}_{1}+\alpha_{2} \mathrm{C}_{2}\right) \mathrm{F}_{1}$

which evaluates the seismic capacity at the failure point of the brittle element. In Fig. 10 this represents the straight line.

The other is an elliptic combination

$E_{0}=\sqrt{E_{1}^{2}+E_{2}^{2}}=\phi \sqrt{\left(C_{1} F_{1}\right)^{2}+\left(C_{2} F_{2}\right)^{2}}$

as shown in Fig. 10. This relationship evaluates the seismic capacity at the failure point of the ductile element.

In order to examine the concept of Eq. (9), the results shown in Fig. 9 were replotted for the entire $E_{1}-E_{2}$ domain in Fig. 11. It shows that the linear or elliptic relationships assumed are very approximate. The use of this concept appears to be reasonable for practical purposes, although more detailed study is needed to improve the evaluation method.

\section{OUTLINE OF EVALUATION METHOD}

\subsection{General}

The evaluation method as compiled by

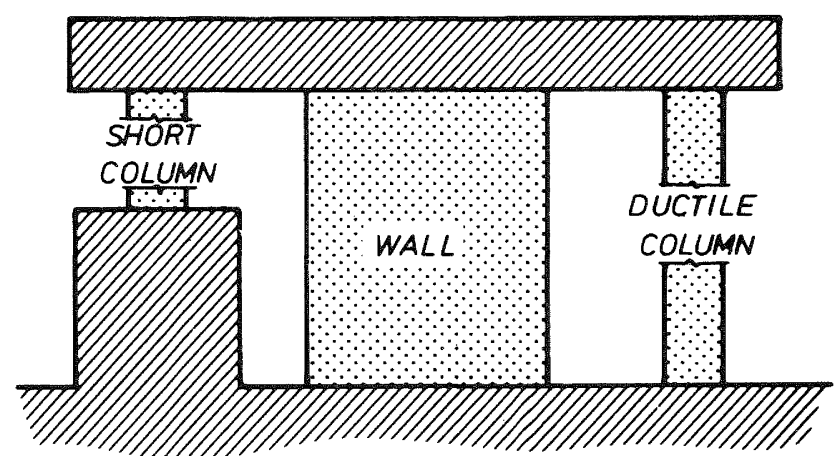

Figure 7 - Idealized Storey of a Building 


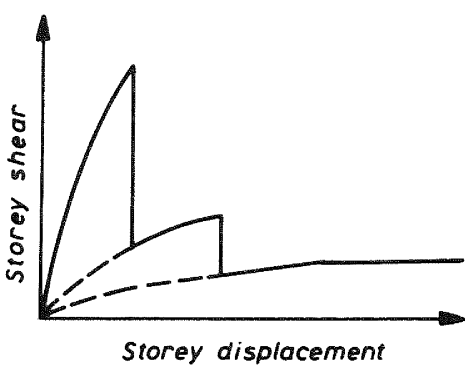

(a) BRITTLE MEMBER DOMINATING

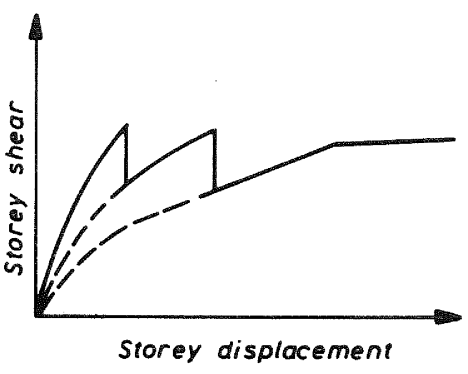

(b) DUCTILE MEMBER DOMINATING

Figure 8 - Storey Shear-Displacement Relationship with Different Vertical Members

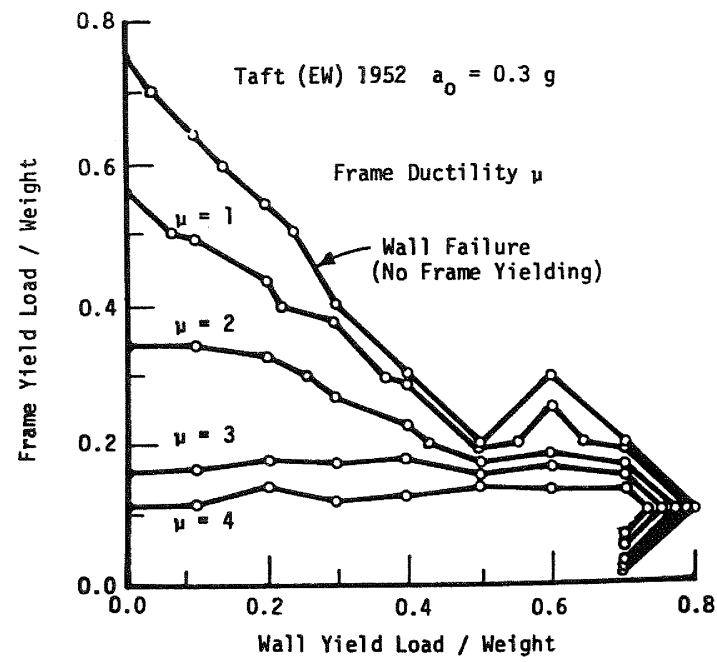

Figure 9 - Earthquake Response of Composite Inelastic Systems

the "Standard for Seismic Capacity Evaluation" is applicable to buildings up to six storeys. The procedure may be applied at three levels. Lower level procedures are simpler, and the result is more conservative. The high level procedure will result in more reliable conclusions, but it involves more complicated analysis. The three-level procedures are intended for application to a group of existing buildings in one area or buildings belonging to the same category, such as "schools". Lower level procedures are used first to screen safe buildings. Higher level procedures are applied subsequently to those buildings only which were not found to be satisfactory by a lower level procedure. All three level procedures have deliberately been made suitable for hand calculation.

The seismic index $I_{s}$ for the total earthquake resisting capacity of a storey in each principal direction of action is defined by the product of four indices:

$I_{S}=E_{O} G S_{D} T$

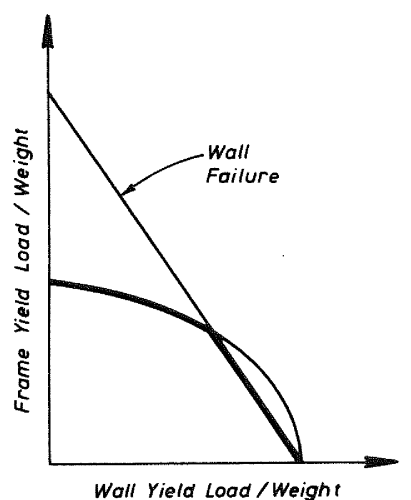

Figure 10 - Idealization of Required Strength of Composite Inelastic Systems

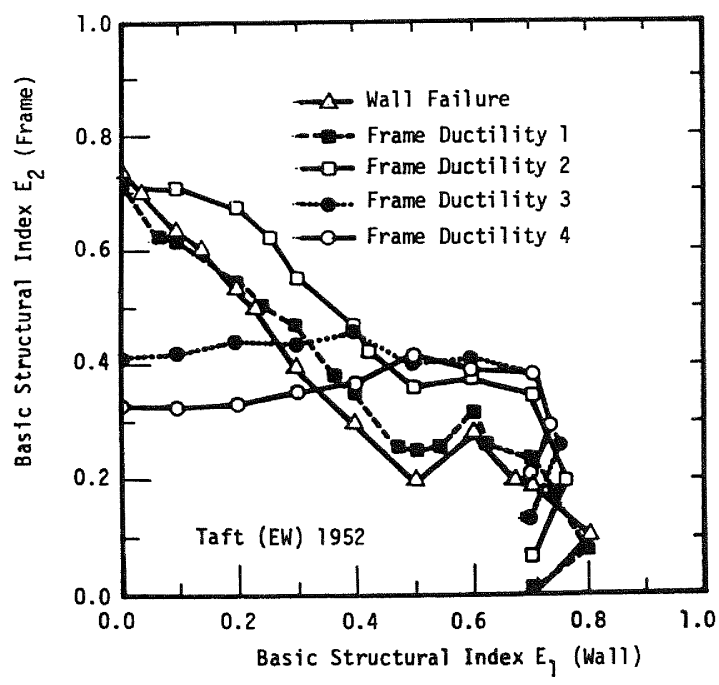

Figure 11 - Basic Structural Indices for Composite Inelastic Systems

where 


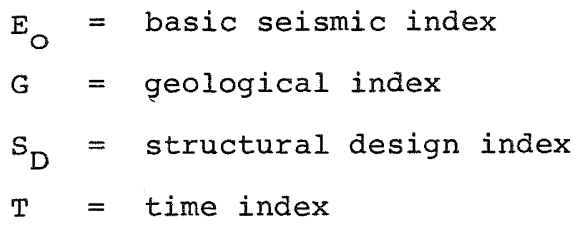

The method of evaluating these indices depend on the level of procedure to be used. The meaning of the last three indices are briefly described in the following.

The geological index was introduced to account for local conditions of the ground which may amplify or attenuate the effective ground motion fed into the structure. Because of lack of information tentatively it is set to 1.0 .

The structural design index was introduced to take into account the disadvantage resulting from unbalanced stiffness distribution in both the plan and the vertical extent of the building, as well as the complexity of the structural layout. These effects were quantified on the basis of observed earthquake damage and engineering judgements. The value for the structural index falls into the range between 1.2 and 0.4 .

The time index was introduced to evaluate the loss of strength and quality in general with age, including (a) cracks due to shrinkage and past overloads, (b) deformations due to uneven settlement of foundations, (c) deterioration of structural materials, (d) past fire damage, and (e) exposure to chemical attack. The range for the value is 1.0 to 0.5 .

\subsection{The First Level Procedure}

The effectiveness of a wall as an earthquake resisting element has been repeatedly demonstrated in many earthquakes, and a good correlation between earthquake damage and the amount of walls relative to total floor area was reported $(5,6)$. This will be discussed subsequently. The first level procedure attempts to evaluate the strength of a storey on the basis of average stresses and the cross sectional area of walls and columns, and to examine whether the structure has adequate strength to withstand earthquake motions without demand for ductility.

The vertical structural elements are classified into three groups:

(a) short columns having clear heightto-depth ratio less than 2 ,

(b) columns, other than short columns, and

(c) walls.

Unit average shear stresses for each of this group were assigned as follows:

1.5 MPa for short columns for clear height-to-depth ratio less than 2 .

1.0 MPa for columns for clear height-todepth ratio between 2 and 6 .
$0.7 \mathrm{MPa}$ for columns for clear height-todepth ratio greater than 6 .

3.0 MPa for walls with two boundary columns.

2.0 MPa for walls with one boundary column.

1.0 MPa for walls without boundary column.

These values were chosen conservatively after studying typical dimensions, material strengths, and reinforcement ratios, used in Japan, and by considering principally shear failure modes. However for columns a flexural failure mode was also considered.

Basic seismic index $E_{O}$ is then evaluated with the following equations:

$$
\begin{aligned}
& \text { When } \mathrm{C}_{\mathrm{SC}}=\mathrm{C}_{\mathrm{W}}=0 \\
& \mathrm{E}_{\mathrm{O}}=\phi \mathrm{C}_{\mathrm{O}} \mathrm{F}_{\mathrm{C}} \\
& \text { When } \mathrm{C}_{\mathrm{SC}}=0 \text { and } \mathrm{C}_{\mathrm{W}} \neq 0 \\
& E_{0}=\phi\left(C_{w}+\alpha_{1} C_{C}\right) F_{w} \\
& \text { When } c_{\text {sc }} \neq 0 \\
& E_{0}=\left(C_{s C}+\alpha_{2} C_{w}+\alpha_{3} C_{C}\right) F_{s C} \\
& \mathrm{C}_{\mathrm{C}} \text { and } \mathrm{F}_{\mathrm{C}}=\text { strength and ductility }
\end{aligned}
$$

Of the two possible combinations of seismic indices for different vertical elements, as indicated by Eqs. (8) and (9), only linear combination was adopted. Therefore the seismic capacity is evaluated at the point of failure of the most brittle element. However, if short columns exist but they are not considered to be critical load-carrying elements, it is permissible to neglect them and use Eqs. (lla) or (llb), and adopt the value of $E_{0}$ thus obtained, or to use the original value from Eq. (1lc), whichever is the greater. Whether a column is a critical load-carrying element or not, can be determined by examining the possible transfer of gravity loads from the column in question, which is assumed to fail, to the neighbouring vertical load-carrying elements.

The first level procedure is useful for buildings with considerable amounts 
of walls (shear walls as well as other types of walls). Although the standard does not consider the contribution of concrete masonry in-fill walls, these may be accounted for using substantiated technical data. In this procedure ductile but relatively weaker structures, such as ductile frames, will be evaluated too conservatively. If after the application of the first level procedure the structure is found to be unsatisfactory, performance evaluation with the next procedure is recommended.

\subsection{The Second Level Procedure}

Flexural yielding in beams is known to be highly beneficial because of the associated large energy dissipation, stable resistance under load reversals and structural stability. On the other hand much damage has been reported in vertical members.

In the second level procedure, beams at the top and bottom of a column are assumed to be infinitely stiff and strong, to enable analysis to be made simple and to pinpoint damage observed in vertical elements. For a weak beamstrong column structure, this usually results in over-estimation of strength and in underestimation of ductility. Considering the prevalent proportions of structural elements in existing structures in Japan, this usually leads to a conservative estimate. For shear walls, vertical continuity is considered in an approximate manner.

This procedure recognizes the following five types of vertical elements:

(a) extremely brittle columns (columns in which shear failure precedes flexural yielding and having a clear height-to-depth ratio of less than 2) ;

(b) shear columns (columns in which shear failure precedes flexural yielding and other than extremely brittle columns of group(a):

(c) shear walls (walls in which shear failure precedes flexural yielding);

(d) flexural columns (columns in which flexural yielding precedes a shear failure:

(e) flexural walls (walls in which flexural yielding precedes a shear failure).

The basic seismic index $E_{O}$ is then evaluated in the following steps.

(1) The flexural and shear strengths of vertical members are evaluated using a set of practical equations. Any rational or empirical equation may be used, and those which were adopted in the standard are contained in the Appendix of this report.

(2) The lateral load carrying capacity of a column at flexural strength is evaluated by assuming the development of its flexural capacity at both ends.
(3) The lateral load carrying capacity of a wall at flexural strength is estimated by assuming the development of its flexural capacity at the base of each storey considered and the presence of a point of contra-flexure situated at the mid-height between the base of the storey and the top of the wall, i.e. usually at roof level. The point of contra-flexure is assumed at the top of the wall for the uppermost storey. A resulting moment diagram is shown in Fig. 12. Selection of the point of contra-flexure as above will allow approximately for the restraining effect of beams framing into the wall.
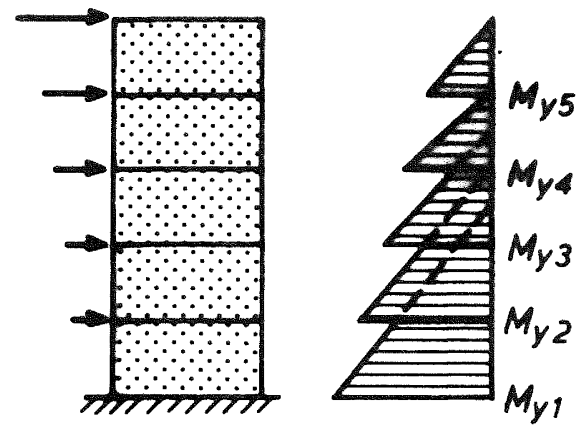

Figure 12 - Assumed Wall Moment Distribution

(4) The value of the ultimate shear strength and the lateral load carrying capacity, are compared in each storey to determine the mode of failure for each vertical member.

(5) Ductility indices of very ductile columns, shear columns, and shear walls are to be assigned according to Table 2 .

(6) The ductility index of a flexural column is determined with Eq. (4). The ductility factor in this equation may be determined by any acceptable method, and the standard recommends the following procedure based on the extensive research sponsored by the Ministry of Construction(13).

$\mu=\mu_{0}-k_{1}-k_{2}$

where

$\mu_{0}=$ basic ductility factor

$\mathrm{k}_{1}=$ correction factor for tie spacing

$\mathrm{k}_{2}=$ correction factor for shear stress level at flexural yielding.

In no case shall $\mu$ be taken less than 1 or greater than 5 .

Values for the basic ductility factor and correction factors are as follows:

$\mu_{0}=10\left(V_{\mathrm{su}} / \mathrm{V}_{\mathrm{u}}-\mathrm{I}\right)$ 
$\mathrm{k}_{1}=0$ when tie spacing is less than eight times the diameter of the main bar

$k_{1}=2.0$ in other cases

$k_{2}=30 \cdot\left(v_{u} / f_{C}^{\prime}-0.1\right) \geqq 0$

where

$\mathrm{V}_{\text {su }}=$ shear strength of column

$\mathrm{v}_{\mathrm{u}}=$ induced shear force at flexural yielding of column

$v_{u}=$ mean shear stress $=v_{u} / 0.8 \mathrm{bh}$ where $b$ and $h$ are the dimensions of the column section.

Large ductility cannot be expected in the presence of large axial load, high shear stress, large tensile reinforcement ratio, or short clear height. Hence the ductility index $F$ is taken to be 1.0 if any one of the following conditions exists:

(axial compression load including seismic loading ) $>0.4 \mathrm{bhf}_{\mathrm{C}}^{\prime}$

(mean shear stress) $>0.2 \mathrm{f}_{\mathrm{C}}^{\prime}$

(tensile reinforcement ratio) >0.01

TABLE 2 - DUCTILITY INDEX F (clear height-to-depth ratio) $\leqq 2.0$

(7) The ductility index for walls may be determined by an appropriate procedure, and tentatively the standard recommends the following method.

$$
\begin{aligned}
& \mathrm{F}=1.0 \text { when } \mathrm{V}_{\mathrm{su}} / \mathrm{V}_{\mathrm{u}} \leqq 1.3 \\
& \mathrm{~F}=2.0 \text { when } \mathrm{V}_{\mathrm{su}} / \mathrm{V}_{\mathrm{u}} \geqq 1.4
\end{aligned}
$$

where

$$
\begin{aligned}
\mathrm{V}_{\text {su }}= & \text { shear strength of wall } \\
\mathrm{V}_{\mathrm{u}}= & \text { shear induced in wall at } \\
& \text { flexural yielding }
\end{aligned}
$$

Linear interpolation should be used for $\mathrm{V}_{\mathrm{su}} / \mathrm{V}_{\mathrm{u}}$ values between 1.3 and 1.4 .

(8) All vertical structural elements of the building are classified according to the appropriate ductility index, into not more than three groups. To each group the smallest ductility index of a member within that group is assigned. The strength index is then determined by dividing the lateral load carrying capacity by the weight above. These indices for strength and ductility are denoted as $\mathrm{C}_{1}, \mathrm{~F}_{1}$ i $\mathrm{C}_{2}, \mathrm{~F}_{2}$ i and $\mathrm{C}_{3}, \mathrm{~F}_{3}$

\begin{tabular}{|c|c|c|c|c|}
\hline & Level (3) & Vertical Member & Definition & $\mathrm{F}$ \\
\hline a & 2,3 & $\begin{array}{l}\text { Extremely } \\
\text { brittle column }\end{array}$ & $\begin{array}{l}\text { Columns in which shear failure precedes } \\
\text { flexural yielding and the clear height- } \\
\text { to-depth ratio less than } 2\end{array}$ & 0.8 \\
\hline $\mathrm{b}$ & 2,3 & Shear column & $\begin{array}{l}\text { Columns in which shear failure precedes } \\
\text { flexural yielding and other than extrem- } \\
\text { ely brittle columns }\end{array}$ & 1.0 \\
\hline c & 2,3 & Shear wall & $\begin{array}{l}\text { Walls in which shear failure precedes } \\
\text { flexural yielding }\end{array}$ & 1.0 \\
\hline$d$ & 2,3 & Flexural column & $\begin{array}{l}\text { Columns in which flexural yielding } \\
\text { precedes a shear failure. }\end{array}$ & $1.27 \sim 3.2^{(1)}$ \\
\hline $\bar{e}$ & 2,3 & Flexural wall & $\begin{array}{l}\text { Walls in which flexural yielding pre- } \\
\text { cedes a shear failure }\end{array}$ & $1.0 \sim 2.0^{(2)}$ \\
\hline$f$ & & $\begin{array}{l}\text { Column governed } \\
\text { by shear beams }\end{array}$ & $\begin{array}{l}\text { Columns whose loading is governed by } \\
\text { beams in which shear failure precedes } \\
\text { flexural yielding }\end{array}$ & 1.5 \\
\hline$q$ & 3 & $\begin{array}{l}\text { Column governed } \\
\text { by flexural } \\
\text { beams }\end{array}$ & $\begin{array}{l}\text { Columns whose loading is governed by } \\
\text { beams in which flexural yielding } \\
\text { precedes a shear failure }\end{array}$ & 3.0 \\
\hline $\mathrm{h}$ & 3 & Rotating wall & $\begin{array}{l}\text { Walls in which rotation due to uplift } \\
\text { of foundation precedes flexural yielding } \\
\text { or shear failure of the wall itself }\end{array}$ & 3.0 \\
\hline
\end{tabular}
value.

(9) The basic seismic index is subsequently calculated by the following two equations:

(1) According to Eq. (4) in text

(2) According to Eq. (14) in text

(3) Refers to level of procedure 
$E_{0}=\phi\left(C_{1}+\alpha_{2} C_{2}+\alpha_{3} C_{3}\right) \cdot F_{1}$

$E_{\circ}=\phi \sqrt{\left(C_{1} F_{1}\right)^{2}+\left(C_{2} F_{2}\right)^{2}+\left(C_{3} F_{3}\right)^{2}}$

where $\phi=$ storey index from Eq. (7)

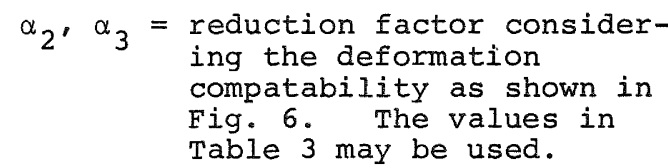

$\underline{\text { TABLE } 3}-\frac{\text { VALUES OF REDUCTION FACTOR }}{{\underline{\text { AND } \alpha_{3}}}_{3}} 2$

\begin{tabular}{|c|c|c|c|}
\hline Cases & $F_{1}=0.8$ & $F_{1}=1.0$ & $F_{1}>1.0$ \\
\hline$F_{2}=1.0$ & $\alpha_{2}=0.7$ & \\
$F_{3}>1.0$ & $\alpha_{3}=0.5$ & & \\
\hline$F_{2}>1.0$ & $\alpha_{2}=0.5$ & $\alpha_{2}=0.7$ & $\alpha_{2}=1.0$ \\
$F_{3}>1.0$ & $\alpha_{3}=0.5$ & $\alpha_{3}=0.7$ & $\alpha_{3}=1.0$ \\
\hline
\end{tabular}

(10) When the structure does not contain extremely brittle columns, the larger of $E$ values derived from Eqs. (15) or 0 (16) may be adopted. However if there are shear columns which are critical load-carrying elements, the $E_{0}$ value from Eq. (15) must be used with $\mathrm{F}_{1}=1.0$.

(11) When the structure contains extremely brittle columns which are critical load-carrying elements, the $E_{0}$ value from Eq. (15) shall be used with $F_{1}=0.8$. When the structure contains extremely brittle columns which, however, are not critical loadcarrying elements, the larger of the above value and $E$ values from Eqs. (15) and (16), neglecting the extremely brittle elements, may be adopted. However, if in this case the building contains some shear columns which are critical loadcarrying elements, only the $E_{0}$ value given by Eq. (15) may be compared with the one considering extremely brittle columns.

(12) Eccentricity is taken into account in the assessment of structural design index $\mathrm{S}_{\mathrm{D}}$. When the eccentricity exceeds a certain limit, given in the Standard, the $\mathrm{E}_{0}$ values must be re-evaluated and taken as the smaller of the following:

(a) $E_{0}$ value calculated by the above method but neglecting the vertical members causing eccentricity:

(b) the $\mathrm{E}_{\mathrm{O}}$ Value from Eq. (15), by placing the vertical members causing eccentricity into the first group $\left(C_{1}, F_{2}\right)$ and by neglecting any vertical members having smaller ductility index.

\subsection{Third Level Procedure}

A structure which can develop flexural yielding at beam ends dissipates vibrational energy through flexural hysteresis, and attains large ductility. The base of a wall may uplift due to a large overturning moment, thereby limiting the lateral load entering the structure and thus adding more lateral deformation capability.

In order to consider such structural behaviour realistically, the third level procedure recognizes three additional types of vertical members as shown in Table 2, namely:

(f) columns governed by shear beams

(g) columns governed by flexural beams

(h) rotating walls.

The basic seismic index, $\mathrm{E}_{\mathrm{O}}$, for the third level procedure, is evaluated in the following steps.

(1) The flexural and shear strengths of vertical and horizontal members are evaluated using practical equations. Those for beams recommended in the Standard are included in the Appendix. Floor slabs may be considered as a part of beams.

(2) For columns and beams, flexural and shear strengths are compared assuming plastic hinges at both ends of the clear span (gravity loads on beams must also be considered). Ductility index $F$ of members is determined accordingly. If the shear strength is found to be smaller, the flexural yield capacity at each end is reduced proportionally to match the shear capacity. This reduced flexural capacity may be termed the shear ultimate moment. By extrapolating moment diagram, nodal ultimate capacities controlled by flexure or in shear in beams and columns are determined. Nodes refer to the intersections of beam and column centre lines.

(3) At each node, the sum of beam moments and the sum of column moments so derived are compared, to determine the nodal failure mode and the nodal ductility index $F$. When the sum of the beam moments is smaller, half of this sum is substituted for the upper and lower column moments. F values of the left and right beams may be averaged. In this step, the strength of the beam-column joints is assumed to be infinite. This assumption was made because of the absence of evidence that damage resulted from weakness of beam-column connections alone. This observation led to an engineering judgement that strength of beam-column connections need not be evaluated in the assessment of overall seismic capacity of existing buildings. 
(4) Failure modes and associated ductility indices $F$, of each column are determined from the smaller value of $F$ at the top and bottom nodes. Ultimate shear in each column is also calculated from the nodal moments.

For walls, a static analysis is carried out assuming inverted triangular lateral load distribution and using known nodal ultimate moments of adjoining beams, to determine whether any storey would fail in flexure or shear, or if the foundation would uplift. The associated moment and shear distribution is then found. modes and ductility indices are common to all storeys of a wall.

(6)

The classification of vertical structural elements, and the calculation of the basic seismic index, are exactly the same as in steps (8) through (12) in the second level procedure. The only additional consideration is that in the calculation of storey index $\phi$ in Eq.s. (15) and (16), Eq. (6) may be used when the seismic capacity is governed by the flexural yielding of beams, flexural yielding of walls at the base or by uplift of walls. In these cases it is believed that the vibration mode is reasonably close to linear (i.e. assumed shape of first mode) even in the inelastic range, and this justifies the use of less conservative Eq. (6).

\section{APPLICATION OF EVALUATION METHOD}

Shiga evaluated and presented the "wall area index" vs "average shear stress" relation for reinforced concrete buildings which responded to the 1968 Tokachioki earthquake $(5,6)$, as shown in Fig. 13. The horizontal axis is wall area index, which is the ratio of total wall area in each direction, $\sum A_{f}$. The vertical axis gives the average shear stress in the walls and columns assuming $1.0 \mathrm{~g}$ response. $\mathrm{W}$ is weight in $\mathrm{N}$, and $\Sigma A_{W}$ and $\Sigma A_{C}$ are total wall and column areas respectively in $\mathrm{mm}^{2}$. A nominal building weight of $10 \mathrm{kPa}$ was assumed in calculating the ordinates.

As it is seen in Fig. 13, buildings which lie outside the shaded area bounded by the wall area index $\sum \mathrm{A}_{\mathrm{W}} / \sum \mathrm{A}_{\mathrm{f}}=0.003$ and the average shear stress $\mathrm{W} /\left(\sum \mathrm{A}_{\mathrm{W}}+\sum \mathrm{A}_{\mathrm{C}}\right)=1.2 \mathrm{MPa}$ are predicted to suffer no damage, while those within the shaded rectangle were found to be mostly damaged except for one group of buildings. These are mostly c-type school buildings having a frame structure with many slender columns with short beam spans in two horizontal directions.

Also shown in Fig. 13 are two solid curves, one for $\Sigma A_{C}=0$, i.e. structures consisting of shear walls only without columns, and another one for $\Sigma A_{C}=\Sigma A_{W}$, i.e. structures having equal amounts of

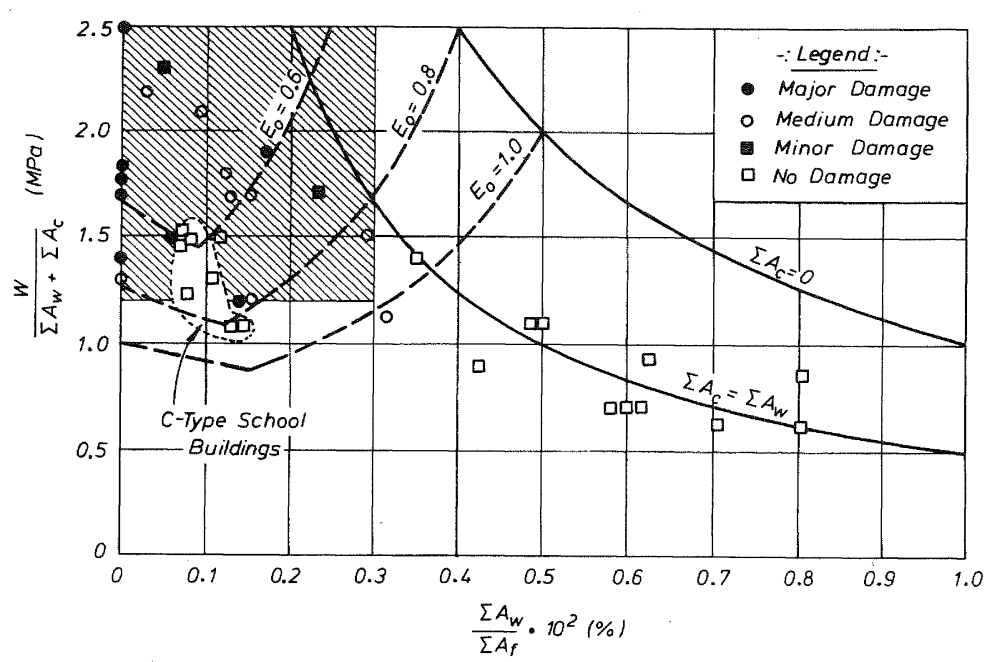

Figure 13 - Wall Area Index and Average Shear Stress in Walls and Columns

wall and column cross-sections. These curves will facilitate the interpretation of responses of buildings without damage.

The broken curves in Fig. 13 show the values for the basic seismic index $\mathrm{E}_{\mathrm{O}}$, derived in the first level evaluation. They were drawn on the basis of the following assumptions:

(1) All columns have clear height-todepth ratios between 2 and 6 . The average shear strength is $1.0 \mathrm{MPa}$.

(2) Equal amounts of walls with two boundary columns, with one boundary column and without boundary column, exist. For any type of wall the average strength is assumed as 2.0 MPa.

(3) Building weight per floor area is taken as $10 \mathrm{kPa}$.

(4) Only the first storey is considered. Therefore the storey index $\phi=1.0$.

Then we obtain

$$
c_{c}=1.0 \sum \mathrm{A}_{C} / \mathrm{W}, \mathrm{C}_{\mathrm{w}}=2.0 \sum \mathrm{A}_{\mathrm{w}} / \mathrm{W}
$$

and from Eq. (11b)

$$
E_{O}=\left(2.0 \sum A_{w}+0.7 \sum A_{C}\right) / W
$$

or from Eq. (lla) neglecting the walls

$$
E_{0}=\Sigma A_{C} / W
$$

Whichever of these expressions gives the greater value of the basic seismic index $\mathrm{E}_{\mathrm{O}^{\prime}}$ is applicable.

Substituting $\Sigma A_{C}$ from above into the expression for average shear stress (the ordinate in Fig. 13) and taking into account that $\mathrm{W}=0.01 \sum \mathrm{A}_{f}$ we obtain

$$
\frac{W}{\sum A_{W}+\sum \cdot A_{C}}=\frac{0.7}{E_{O}-1.3\left(\sum A_{W} / W\right)}
$$




$$
=\frac{0.7}{E_{0}-1.3\left(\frac{\sum A_{w}}{\sum A_{f}} \cdot 10^{2}\right)}
$$

and

$$
\begin{aligned}
& \frac{W}{\sum A_{W}+\sum A_{C}}=\frac{1.0}{E_{O}+\sum A_{W} / W} \\
& =\frac{1.0}{E_{O}+\left(\frac{\sum A_{W}}{\sum A_{f}} \cdot 10^{2}\right)}
\end{aligned}
$$

For $\mathrm{E}_{\mathrm{f}}=1.0,0.8$, and 0.6 curves were drawn lising above equations. Strong dependency of damage on $\mathrm{E}$ values can be seen. Practically, all ${ }^{\circ}$ buildings with $E_{0}$ values greater than 1.0 were undamaged, and almost all buildings with $E_{0}$ values less than 0.6 suffered damage, during the 1968 Tokachioki earthquake. The measured maximum ground acceleration was $23 \%$ of $g$ at Hachinohe Harbour station, but it has been inferred that maximum ground acceleration at the sites of damaged buildings could have reached $30 \%$ of $\mathrm{g}$.

Seven reinforced concrete buildings, all of which were exposed to the 1968 Tokachioki earthquake, were studied using the second level procedure (7) The seismic index values $I_{s}$ from the second level procedure in both longitudinal $(L)$ and transverse ( $T$ ) directions are shown in Fiq. 14, together with the degree of observed damage. It is seen that buildings with I values less than 0.5 suffered major or medium damage, while those with I values greater than 0.7 escaped damaqe, when subjected to the ground motions of the 1968 Tokachioki earthquake.

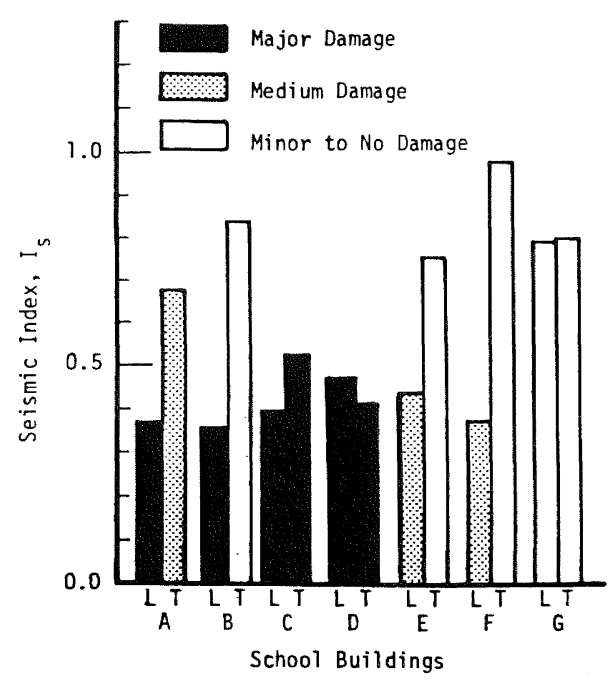

Fiqure 14 - Seismic Index and Damage of School Buildings in 1968 Tokachi-oki Earthquake (Second Level Procedure)
A similar study was carried out of the reinforced concrete buildings subjected to $1978 \mathrm{Izu}$ Ohshima Kinkai Earthquake and the 1978 Miyagiken-oki Earthquake(14). The ground motion in the afflicted area due to the Izu, earthquake was not recorded, but it was judged from structural response that the motion could have been a little less intense than that of the 1968 Tokachioki earthquake. The Miyagiken-oki earthquake struck the city of Sendai (population 600,000 ) and its vicinity, and several records in the area showed maximum ground accelerations of $0.25 \mathrm{~g}$ to $0.30 \mathrm{~g}$. It is believed that the ground motion in the city could have been as strong as that of the 1968 Tokachioki earthquake.

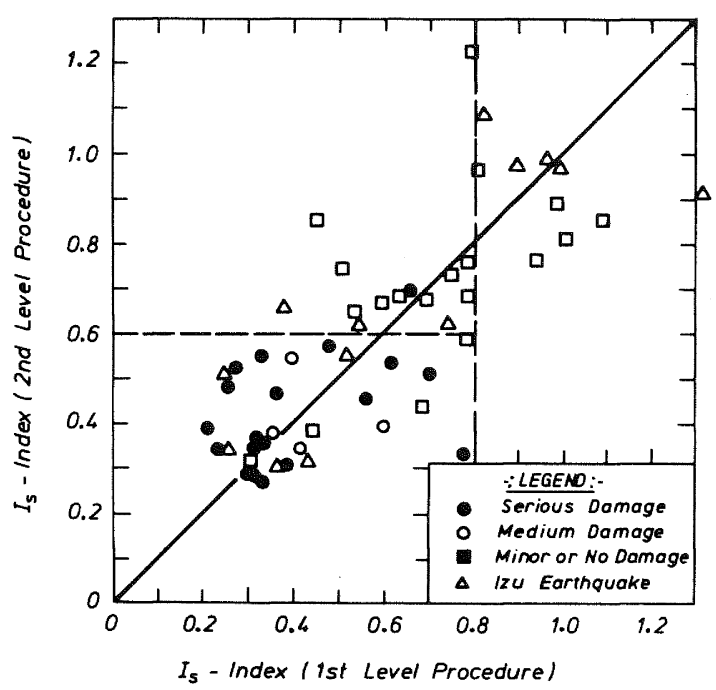

Figure 15 - Seismic Index and Damage in 1978 Earthquakes in Japan

Fig. 15 shows seismic indices of buildings which experienced these earthquakes, calculated both by the first and second level procedures, together with the degree of observed damage. It is seen that the correlation of the results obtained by two procedures is not very good. The intention of "screening" will be very satisfactorily achieved by the procedure, if the $I_{s}$ values from the first level procedure are partitioned at $I_{S}=0.8$, and then the $I_{s}$ values from the second level procedure are partitioned at $I_{s}=0.6$. Buildings that were not found to be safe by these criteria will be subjected to the third level procedure, or any other appropriate methods of evaluation.

The "Standard for Seismic Capacity Evaluation" itself does not specify the value of the seismic index necessary for the protection of existing buildings.

The application of procedures discussed, with respect to buildings which experienced earthquake motions, will give an empirical basis for the selection of the necessary values of seismic index to ensure the protection of existing buildings. 


\section{THE SEISMIC PROTECTION INDEX}

In response to the expressed need for better seismic risk assessment, following the seismologists' prediction of a magnitude eight Tokai earthquake in this century, the Shizuoka Prefectural Government initiated in 1977 a wide range of projects, which included technical as well as \$ociological and economic aspects (15). A committee was formed within the Japan Association for Building Disaster Prevention to cooperate with the Prefectural Government, in the seismic performance evaluation of existing buildings. The committee's achievement includes the development of computer programs for the seismic capacity evaluation. They include a combined first and second level procedure, and the third level procedure. Using the programs, by March, 1980, more than 500 reinforced concrete buildings in the Shizuoka Prefecture were evaluated. The wide use of the seismic capacity evaluation method made it necessary to provide a well defined seismic protection index to enable a comparison with the calculated seismic index to be made. Murakami's work for the committee ${ }^{(1 \dot{4})}$ is summarised as follows:

Theoretically, the basic seismic index $\mathrm{E}$, which is identical with the seismic index $I_{S}$ when the value of all the other modifying indices, such as $G, S_{\text {}}$ and $T$, is unity, can be interpreted as the elastic response acceleration. In other words $E_{0}$ can be compared with a protection index, expressed as a product of ground peak acceleration and the response magnification factor in the form of linear response spectrum. However, in the derivation of Eq. (4) for the ductility index $F$, it was assumed that the response magnification factor is a constant over the period range considered. Also it is well known that the response in the short period range is quite sensitive to several factors involved, such as the frequency contents, the wave form of the accelerogram, types and other selected parameters of linear or nonlinear models. In view of the situation, it was decided that the response magnification factor for the seismic protection index should be evaluated from a statistical response analysis of nonlinear models for families of artificial earthquakes (16). This in effect is a re-examination and a compensation for the degree of approximation involved in Eq. (4).

The basic protection index $\mathrm{E}_{\mathrm{S}}$ is expressed as

$E_{S}=\left\{C_{R} \cdot F\right\} \cdot\left(a_{g} / g\right)$

where $\left(a_{g} / g\right)$ is the ground peak acceleration divided by gravity acceleration, and the response magnification factor $\left(C_{R} \cdot F\right)$ is expressed as the product of strenath ratio $C_{R}$ (strength divided by mass and around peak acceleration) and the ductility index $\mathrm{F}$.
Two nonlinear models were selected. One is the degrading trilinear model shown in Fig. 3, representing a structure primarily failing in flexure. Another is the origin-oriented model, chosen to represent a structure failing in shear. As mentioned the model represents stiffness degradation with no hysteretic energy dissipation.

Figs. 16, 17 and 18 show strength ratio required for the nonlinear models to stay within the prescribed ductility factor at a probability of $0.95(16)$. In these figures the following notation is used:

$\mathrm{T}_{1}=$ period associated with the elastic stiffness

$\mathrm{T}_{2}=$ period associated with the secant stiffness at the first yield point

$\mathrm{P}_{\mathrm{C}}=$ strength developed at cracking

$\mathrm{P}_{\mathrm{y}} \quad=$ yield strength

$\mu_{95}=$ prescribed limit of ductility within which the ductility demand from the nonlinear analysis remains with a probability of 0.95

$\Delta_{\max }=$ prescribed maximum lateral deformation

$\Delta_{y}=$ deformation at the first yield point

$\Delta_{C}=$ deformation at the cracking point

Four types of artificial earthquake motions were used. They represent the following characteristics at a site with a predominant period of $0.4 \mathrm{sec}$.

Type $\mathrm{A}=$ upper bound ground motion expected near a causative fault

Type $B=$ motions close to a fault in a magnitude 7 earthquake

Type C : motions in the epicentral region of a magnitude 6 earthquake

Type D : motions in the immediate vicinity of the fault of a magnitude 5 earthquake with a small focal depth.

As seen in these figures, the required strength is not significantly affected by the choice of earthquake types. It is dependent, of course, on the value of the prescribed ductility factor $\mu_{95}$. When multiplied by the ductility index $F$ from Eq. (4), however, they give almost identical response magnification factors, indicating the validity of the method in the "standard".

By taking into account that these figures were obtained for the predominant site period of $\mathrm{T}_{\mathrm{g}}=0.4 \mathrm{sec}$, the response magnification factor was determined as follows. 
buildings

For flexural yielding type

$C_{R} \cdot F=3.15 \sqrt{2 \mathrm{Tg}} \leqq 3.15$

$(18-1)$

For shear failure type buildings

$C_{R} \cdot F=2.90 \sqrt{\frac{T g}{T}} \leqq 3.15$

As to the natural period $T$ in these equations, reference was made to the assumed deformation at flexural yielding or shear failure as in Fig. 6, which led to the following expression in terms of the total storey number $n$.

For flexural yielding type buildings

$T=0.20 \sqrt[4]{3(n-1)} \geqq 0.2$

For shear failure type buildings

$\mathrm{T}=0.14 \sqrt[4]{3(\mathrm{n}-1)} \geqq 0.14$

The assessment of the possible ground peak acceleration was a more difficult task. From seismological as well as enqineering considerations, the following expression was selected.

$\mathrm{a}_{\mathrm{g}} / \mathrm{g}=(0.36 \sim 0.23) \sqrt{\frac{0.4}{\mathrm{Tg}}}$

The largest value of $a_{g}=0.36 \mathrm{~g}$ for $\mathrm{T}_{\mathrm{g}}=0.4$ sec is to be used in regions where the distance to the predicted epicentral zone of Tokai earthquake is less than $40 \mathrm{~km}$. In selecting this value, account was taken of the possible hysteretic action of the soil in the strong ground shaking, and the permissible increase in the degree of structural damage. The smallest value of $a_{g}=0.23 \mathrm{~g}$ for $\mathrm{T}_{\mathrm{g}}=0.4 \mathrm{sec}$ represents the average seismicity prevalent in the Shizuoka Prefecture, and is to be used in the regions where distance to the predicted epicentral zone is greater than $70 \mathrm{~km}$. For the area between these two regions, interpolation was suggested, based on Japanese attenuation data. This turned out to be almost a linear interpolation.

By substituting Eqs. (18), (19), (20) into Eq. (17), the basic protection index is found. For ground peak accelerations of $0.36 \mathrm{~g}$ and $0.23 \mathrm{~g}$, values of $E_{\text {s }}$ are given in Table 4. For practical applications the values are rounded to the nearest 0.05 . Values for flexural yielding type buildings may be used where the major portion of seismic capacity is due to the capacity of ductile members. When the major portion of seismic capacity comes from brittle members, or the capacity consists of the mixture of both kinds of failure mechanisms, values for shear failure type buildings should be used.

To generalize the seismic protection index for practical application, the following form of derivation was finally adopted.
$E_{T}=E_{S} \quad C_{G} C_{I}$

where

$\mathrm{E}_{\mathrm{T}}=$ seismic protection index

$E_{S}=$ basic seismic protection index from Eq. (17)

$\mathrm{C}_{\mathrm{G}}=$ correction factor for topography. At the edge of a cliff, on unconformable strata or on a hill, the value is 1.25 , otherwise its value is 1.0 .

$C_{I}=$ importance factor. This may be taken equal to or greater than 1.25 for important buildings, otherwise $C_{I}=1.0$

The seismic protection index, as proposed in Table 4 , was applied to approximately 500 government-owned buildings in the Shizuoka Prefecture. These buildings were all reinforced concrete structures. predominantly they were ten to twenty years old. It was found that the index of about fifteen percent of these buildings fell below sixty percent of the value of proposed seismic protection index. They are mostly buildings located in the area whose epicentral distance to the predicted Tokai earthquake is less than $40 \mathrm{~km}$. Furthermore it was found that there was a remarkable difference between buildings designed before and after 1971, the year in which revision of building code, as a result of 1968 Tokachioki earthquake, was enforced. These findings will assist the local government in the administration of their buildings.

In the course of development of seismic protection index, it was intended that the protection index should be applicable principally with the second level procedure of the evaluation. The application to Shizuoka buildings, described above, was in fact with the second level procedure. Although there is only a limited amount of experience available, it appears that the protection index is appropriate for Japanese buildings evaluated by the second level procedure of the "standard". It is believed that the protection index is equally applicable to the third level procedure. More experience is necessary, however, before any conclusion can be drawn for this case.

\section{AN EXAMPLE OF SEISMIC CAPACITY EVAL- UATION}

A hypothetical New Zealand building was examined with the Japanese seismic capacity evaluation method, primarily to illustrate the application of the evaluation procedure numerically. The selected structure is that of a four storey office building, with 3 spans in $\mathrm{x}$-direction and 4 spans in $\mathrm{y}$-direction consisting of ductile frames without shear walls. The roof structure, however, is completely different from the original structure. The structural plan of the typical floor is shown in Fig. 19. A typical frame in the $x$-direction is shown in Fig. 20. Foundation consists of continuous footings running in the $x-$ direction, and heavy foundation beams are provided in the $y$-direction. 

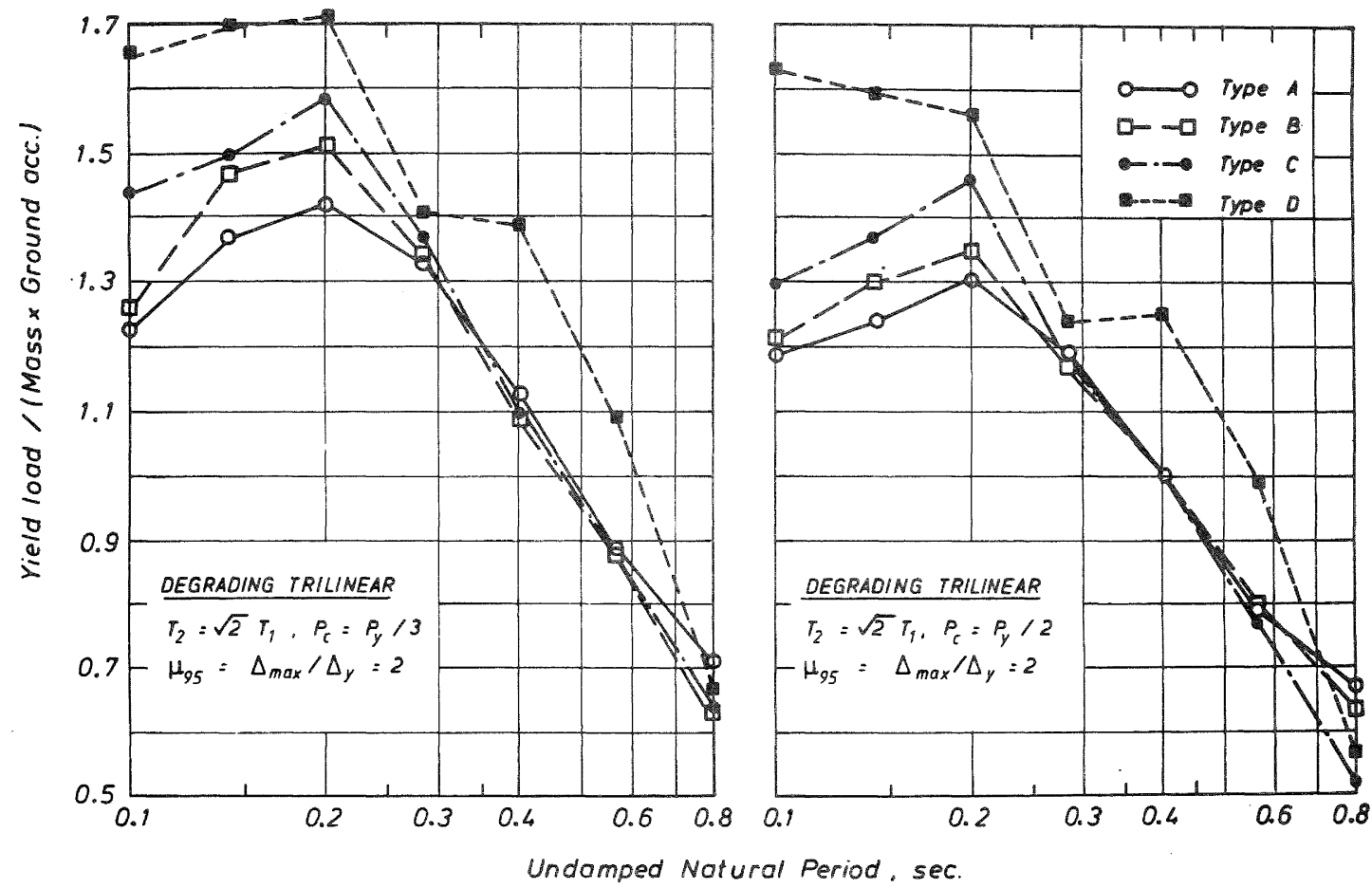

Figure 16 - Required Strength Ratio of Degrading Trilinear Model for $\mu_{95}=2$

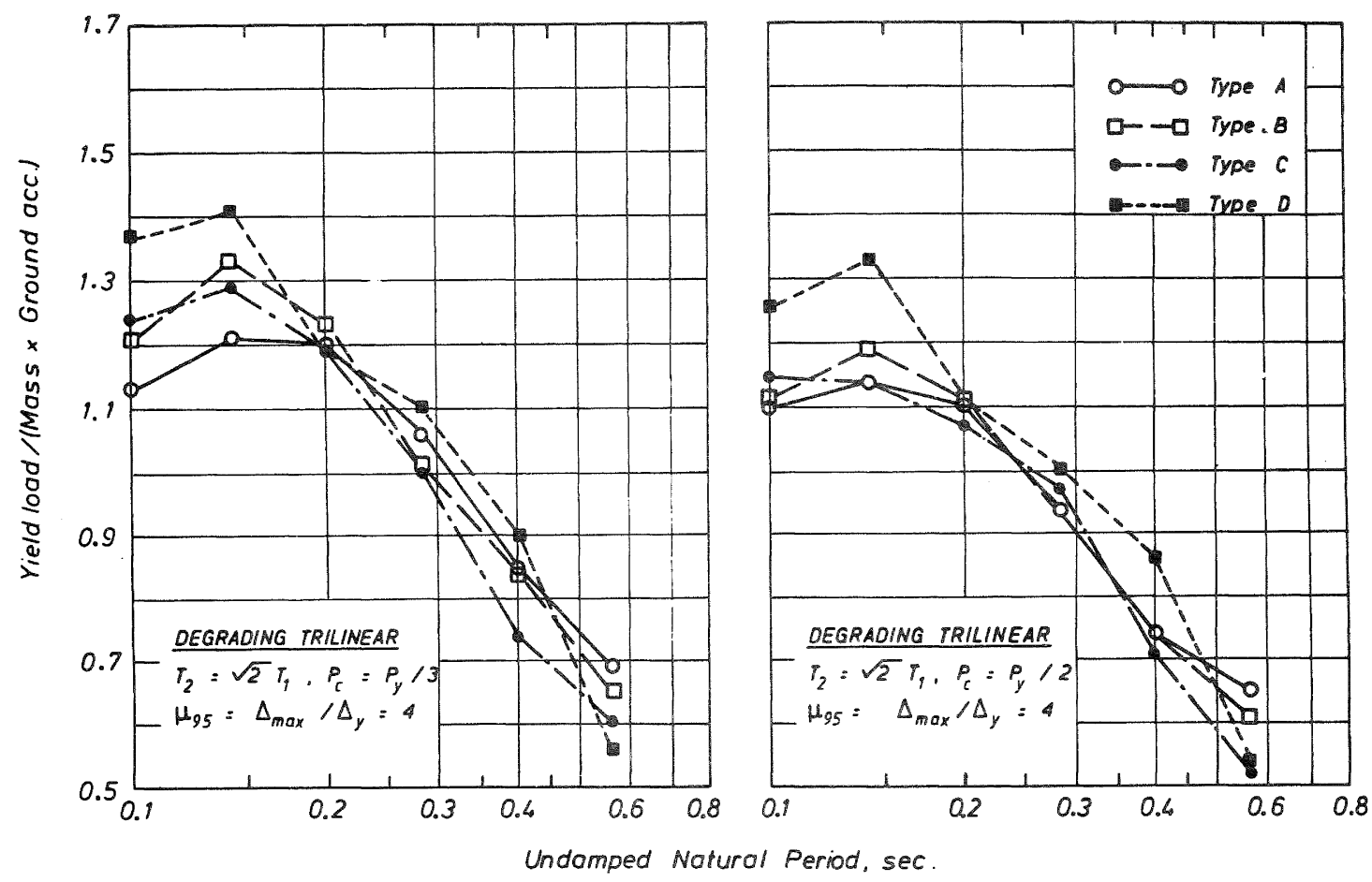

Figure 17 - Required Strength Ratio of Degrading Trilinear Model for $\mu_{95}=4$ 


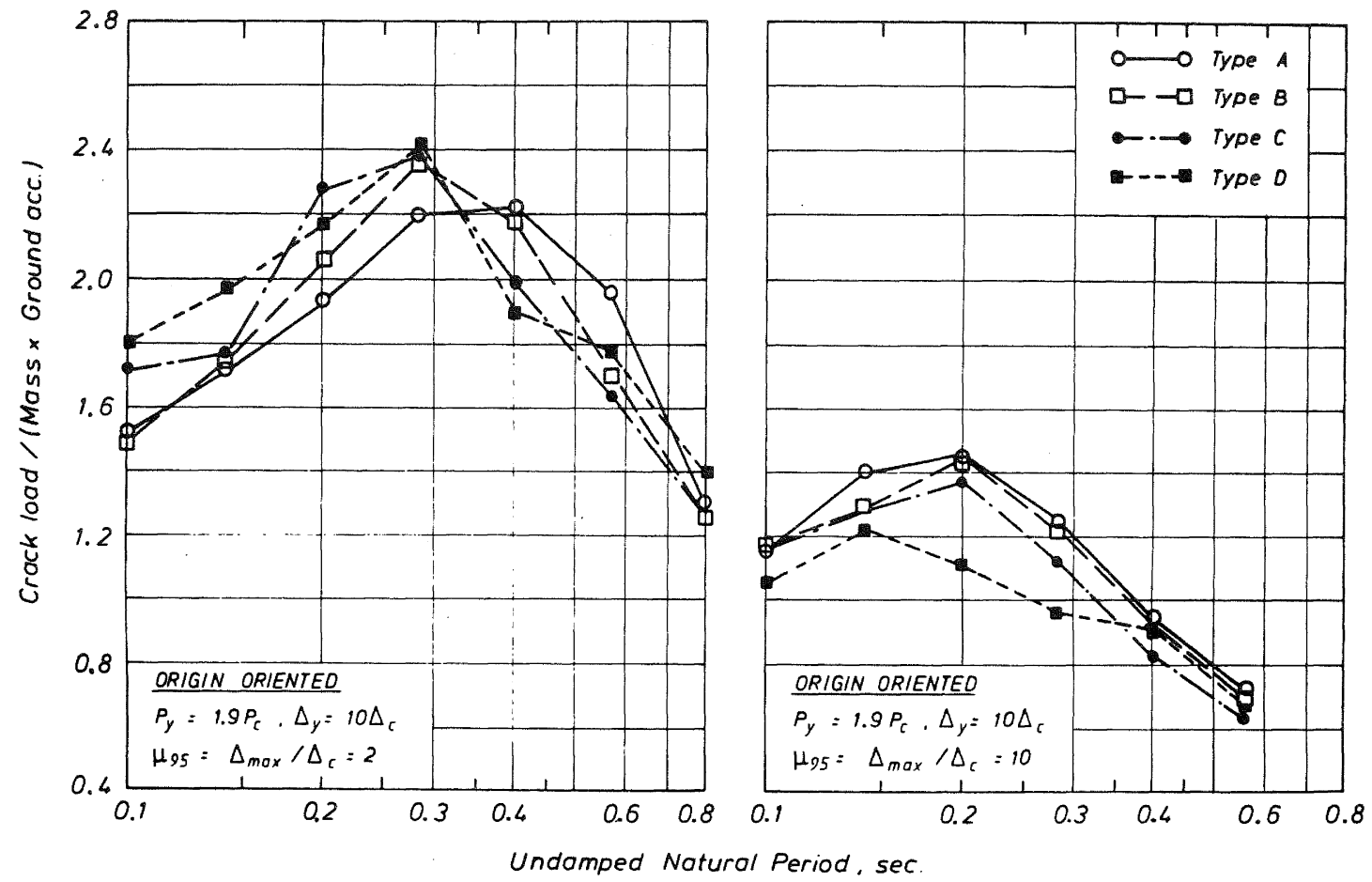

Figure 18 - Required Strength Ratio of Origin Oriented Model

TABLE 4 : BASIC SEISMIC PROTECTION INDEX $E_{S}$ Upper figures : shear failure type building

Lower figures : flexural failure type building

\begin{tabular}{|c|c|c|c|c|c|c|c|}
\hline \multirow{2}{*}{$\begin{array}{l}\text { Peak Ground } \\
\text { acceleration } \\
\text { ratio } a_{\mathrm{g}} / \mathrm{g}\end{array}$} & \multirow{2}{*}{$\begin{array}{c}\text { No. of } \\
\text { storeys } \\
n\end{array}$} & \multicolumn{6}{|c|}{ Predominant Period of the Ground $\mathrm{T}_{\mathrm{g}}$ (secs) } \\
\hline & & 0.3 & 0.4 & 0.5 & 0.6 & 0.7 & 0.8 \\
\hline \multirow{6}{*}{0.36} & 1 & $\begin{array}{l}1.25 \\
1.10 \\
\end{array}$ & $\begin{array}{l}1.10 \\
1.10\end{array}$ & $\begin{array}{l}1.00 \\
1.00 \\
\end{array}$ & $\begin{array}{l}0.90 \\
0.90 \\
\end{array}$ & $\begin{array}{l}0.85 \\
0.85 \\
\end{array}$ & $\begin{array}{l}0.80 \\
0.80 \\
\end{array}$ \\
\hline & 2 & $\begin{array}{l}1.10 \\
0.95 \\
\end{array}$ & $\begin{array}{l}1.10 \\
0.95 \\
\end{array}$ & $\begin{array}{l}1.00 \\
0.95 \\
\end{array}$ & $\begin{array}{l}0.90 \\
0.90 \\
\end{array}$ & $\begin{array}{l}0.85 \\
0.85 \\
\end{array}$ & $\begin{array}{l}0.80 \\
0.80 \\
\end{array}$ \\
\hline & 3 & $\begin{array}{l}1.00 \\
0.90 \\
\end{array}$ & $\begin{array}{l}1.00 \\
0.90 \\
\end{array}$ & $\begin{array}{r}1.00 \\
0.90 \\
\end{array}$ & $\begin{array}{l}0.90 \\
0.90 \\
\end{array}$ & $\begin{array}{l}0.85 \\
0.85 \\
\end{array}$ & $\begin{array}{l}0.80 \\
0.80 \\
\end{array}$ \\
\hline & 4 & $\begin{array}{l}0.95 \\
0.85 \\
\end{array}$ & $\begin{array}{l}0.95 \\
0.85 \\
\end{array}$ & $\begin{array}{l}0.95 \\
0.85 \\
\end{array}$ & $\begin{array}{l}0.90 \\
0.85 \\
\end{array}$ & $\begin{array}{l}0.85 \\
0.85 \\
\end{array}$ & $\begin{array}{l}0.80 \\
0.80 \\
\end{array}$ \\
\hline & 5 & $\begin{array}{l}0.90 \\
0.85 \\
\end{array}$ & $\begin{array}{l}0.90 \\
0.85 \\
\end{array}$ & $\begin{array}{l}0.90 \\
0.85 \\
\end{array}$ & $\begin{array}{l}0.90 \\
0.85 \\
\end{array}$ & $\begin{array}{l}0.85 \\
0.85 \\
\end{array}$ & $\begin{array}{l}0.80 \\
0.80 \\
\end{array}$ \\
\hline & 6 & $\begin{array}{l}0.90 \\
0.80\end{array}$ & $\begin{array}{l}0.90 \\
0.80 \\
\end{array}$ & $\begin{array}{r}0.90 \\
0.80 \\
\end{array}$ & $\begin{array}{l}0.90 \\
0.80 \\
\end{array}$ & $\begin{array}{l}0.85 \\
0.80 \\
\end{array}$ & $\begin{array}{l}0.80 \\
0.80 \\
\end{array}$ \\
\hline \multirow{6}{*}{0.23} & 1 & $\begin{array}{l}0.80 \\
0.70 \\
\end{array}$ & $\begin{array}{l}0.70 \\
0.70 \\
\end{array}$ & $\begin{array}{l}0.65 \\
0.65 \\
\end{array}$ & $\begin{array}{l}0.60 \\
0.60 \\
\end{array}$ & $\begin{array}{l}0.55 \\
0.55 \\
\end{array}$ & $\begin{array}{l}0.50 \\
0.50 \\
\end{array}$ \\
\hline & 2 & $\begin{array}{l}0.70 \\
0.60 \\
\end{array}$ & $\begin{array}{l}0.70 \\
0.60 \\
\end{array}$ & $\begin{array}{l}0.65 \\
0.60 \\
\end{array}$ & $\begin{array}{l}0.60 \\
0.60 \\
\end{array}$ & $\begin{array}{l}0.55 \\
0.55 \\
\end{array}$ & $\begin{array}{l}0.50 \\
0.50 \\
\end{array}$ \\
\hline & 3 & $\begin{array}{l}0.65 \\
0.60 \\
\end{array}$ & $\begin{array}{l}0.65 \\
0.60 \\
\end{array}$ & $\begin{array}{l}0.65 \\
0.60 \\
\end{array}$ & $\begin{array}{l}0.60 \\
0.60 \\
\end{array}$ & $\begin{array}{l}0.55 \\
0.55 \\
\end{array}$ & $\begin{array}{l}0.50 \\
0.50 \\
\end{array}$ \\
\hline & 4 & $\begin{array}{l}0.60 \\
0.55 \\
\end{array}$ & $\begin{array}{l}0.60 \\
0.55 \\
\end{array}$ & $\begin{array}{l}0.60 \\
0.55 \\
\end{array}$ & $\begin{array}{l}0.60 \\
0.55 \\
\end{array}$ & $\begin{array}{l}0.55 \\
0.55 \\
\end{array}$ & $\begin{array}{l}0.50 \\
0.50 \\
\end{array}$ \\
\hline & 5 & $\begin{array}{l}0.60 \\
0.55 \\
\end{array}$ & $\begin{array}{l}0.60 \\
0.55 \\
\end{array}$ & $\begin{array}{r}0.60 \\
0.55 \\
\end{array}$ & $\begin{array}{l}0.60 \\
0.55 \\
\end{array}$ & $\begin{array}{l}0.55 \\
0.55 \\
\end{array}$ & $\begin{array}{l}0.50 \\
0.50 \\
\end{array}$ \\
\hline & 6 & $\begin{array}{l}0.60 \\
0.50\end{array}$ & $\begin{array}{l}0.60 \\
0.50\end{array}$ & $\begin{array}{l}0.60 \\
0.50\end{array}$ & $\begin{array}{l}0.60 \\
0.50\end{array}$ & $\begin{array}{l}0.55 \\
0.50\end{array}$ & $\begin{array}{l}0.50 \\
0.50\end{array}$ \\
\hline
\end{tabular}


Fig. 21 shows typical sections of columns and girders. Structural members had been designed with the capacity design method. They were somewhat simplified for the purpose of this evaluation procedure.

Table 5 shows column axial loads and floor weights. As the objective of this example is only to illustrate the procedure, these quantities were simply obtained from the tributary areas and the assumed average weight of $10 \mathrm{kPa}$, without a more accurate load evaluation.

The first level procedure is summarized in Table 6. As the vertical members are only columns, the procedure is very simple. The basic seismic index $E_{O}$ is obtained using Eq.

(11a). Because of the conservative assumption made in the "Standard" that the value of ductility index $F$ for columns be taken as 1.0 , the values for $E_{0}$ are rather low. In the first storey, $E_{O}=I_{S}=0.51$. This was to be expected. It is evident that the first level procedure is inadequate for a ductile frame building.
The second level procedure requires evaluation of flexural and shear strengths of vertical members, and the value of the ductility factor when the member is expected to fail in flexure. Table 7 shows the calculation of strengths using the relevant Japanese equations collated in the Appendix. The ductility factor was obtained Eq. (12). Earthquake induced column axial load was not considered in Table 7. As seen all columns have sufficient shear capacity to prevent premature shear failure even when hinges would form at both ends of the columns.

Table 8 shows the summary of the second level procedure. The basic seismic index is calculated by Eqs.(15) and (16), and the larger of the two was selected. It should be noted that rearrangement of three groups of vertical members into two groups is permissible, if it results in higher E values.

When a weak beam-strong column type frame structure is evaluated by the second level procedure, which assumes infinitely strong beams, normally the strength is overestimated and ductility is underestimated. In this example, the resulting seismic index is very high. The lowest value at the first storey is $\mathrm{E}_{\mathrm{O}}=\mathrm{I}_{\mathrm{S}}=1.32$.

TABLE 5 : COLUMN AXIAL LOAD AND TOTAL BUILDING WEIGHT (approximated using tributary floor area and assumed average weight of $10 \mathrm{kPa}$ )

\begin{tabular}{|c|c|c|c|c|c|}
\hline Member & Storey & \multicolumn{2}{|c|}{ Calculation } & $\begin{array}{l}\text { Load } \\
(\mathrm{kN})\end{array}$ & $\begin{array}{c}\text { Total Load } \\
(\mathrm{kN})\end{array}$ \\
\hline$c_{a}$ & $\begin{array}{l}4 \\
3 \\
2 \\
1\end{array}$ & $(0.575+3)^{2} \times 10$ & $=$ & $\begin{array}{l}128 \\
128 \\
128 \\
128\end{array}$ & $\begin{array}{l}128 \\
256 \\
384 \\
512\end{array}$ \\
\hline $\mathrm{C}_{\mathrm{b}}$ & $\begin{array}{l}4 \\
3 \\
2 \\
1\end{array}$ & $(0.575+3) \times 6 \times 10$ & $=$ & $\begin{array}{l}215 \\
215 \\
215 \\
215\end{array}$ & $\begin{array}{l}215 \\
430 \\
645 \\
860\end{array}$ \\
\hline $\mathrm{c}_{\mathrm{c}}$ & $\begin{array}{l}4 \\
3 \\
2 \\
1\end{array}$ & $6 \times 6 \times 10$ & $=$ & $\begin{array}{l}360 \\
360 \\
360 \\
360\end{array}$ & $\begin{array}{r}360 \\
720 \\
1080 \\
1440\end{array}$ \\
\hline $\begin{array}{l}\text { Total } \\
\text { Floor }\end{array}$ & $\begin{array}{l}4 \\
3 \\
2 \\
1\end{array}$ & $19.15 \times 25.15 \times 10$ & $=$ & $\begin{array}{l}4820 \\
4820 \\
4820 \\
4820\end{array}$ & $\begin{array}{r}4820 \\
9640 \\
14460 \\
19280\end{array}$ \\
\hline
\end{tabular}

TABLE 6 : QUANTITIES FOR THE FIRST LEVEL PROCEDURE

\begin{tabular}{|c|c|c|c|c|c|c|c|c|}
\hline Direction & Storey & Type & $C^{(I)}$ & $F$ & $E_{O}$ & $S_{D}$ & $T^{T}$ & $I_{S}$ \\
\hline \multirow{3}{*}{$\mathrm{X}, \mathrm{Y}$} & 4 & $\mathrm{COL}$ & 2.033 & 1.0 & 1.27 & 1.0 & 1.0 & 1.27 \\
\cline { 2 - 9 } & 3 & $\mathrm{COL}$ & 1.017 & 1.0 & 0.73 & 1.0 & 1.0 & 0.73 \\
\cline { 2 - 9 } & 2 & $\mathrm{COL}$ & 0.678 & 1.0 & 0.57 & 1.0 & 1.0 & 0.57 \\
\cline { 2 - 9 } & 1 & $\mathrm{COL}$ & 0.508 & 1.0 & 0.51 & 1.0 & 1.0 & 0.51 \\
\hline
\end{tabular}

(1) For all storeys, total column area $\sum A=700^{2} \times 200=9.8 \times 10^{6} \mathrm{~mm}^{2}$ therefore $C_{C} \cdot W=1.0 \times 9.8 \times 10^{6} / 10^{3 C}=9800 \mathrm{kN}$ 


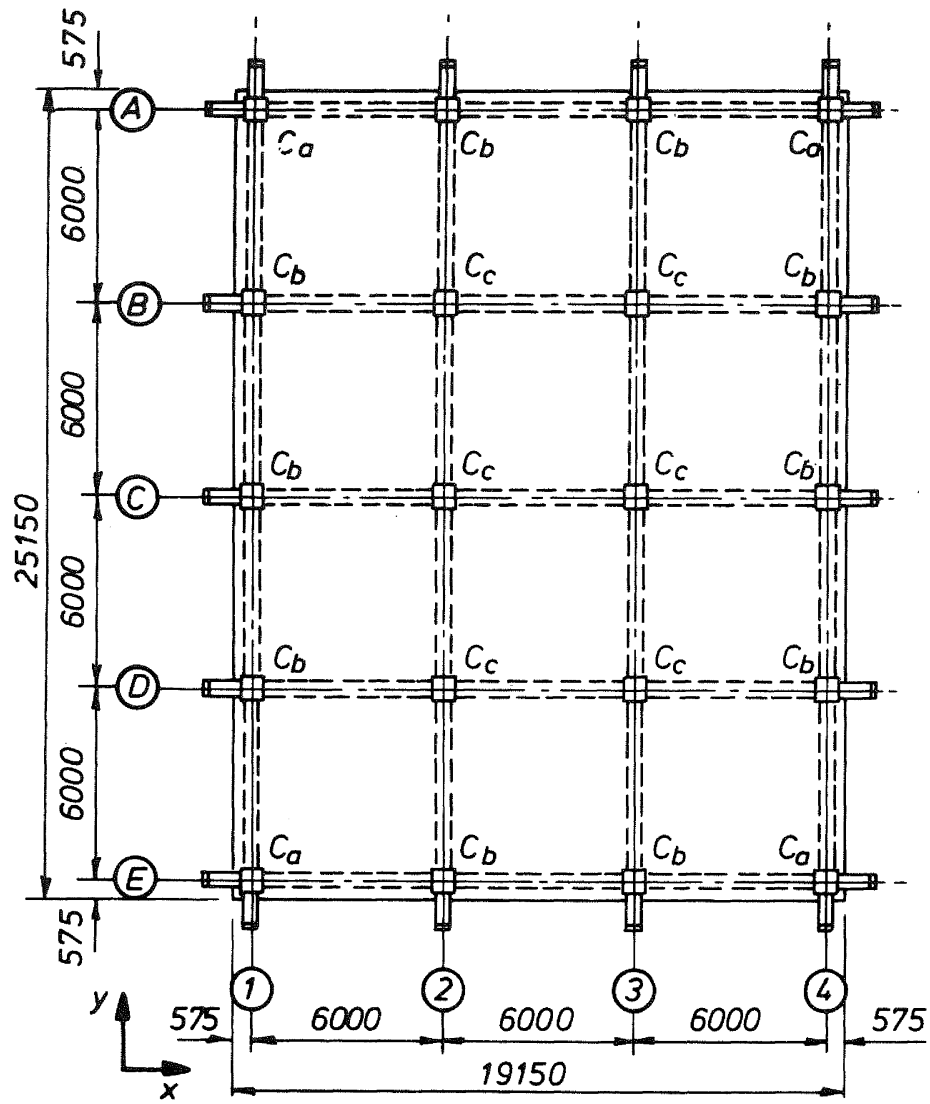

Figure 19 - Typical Floor Plan

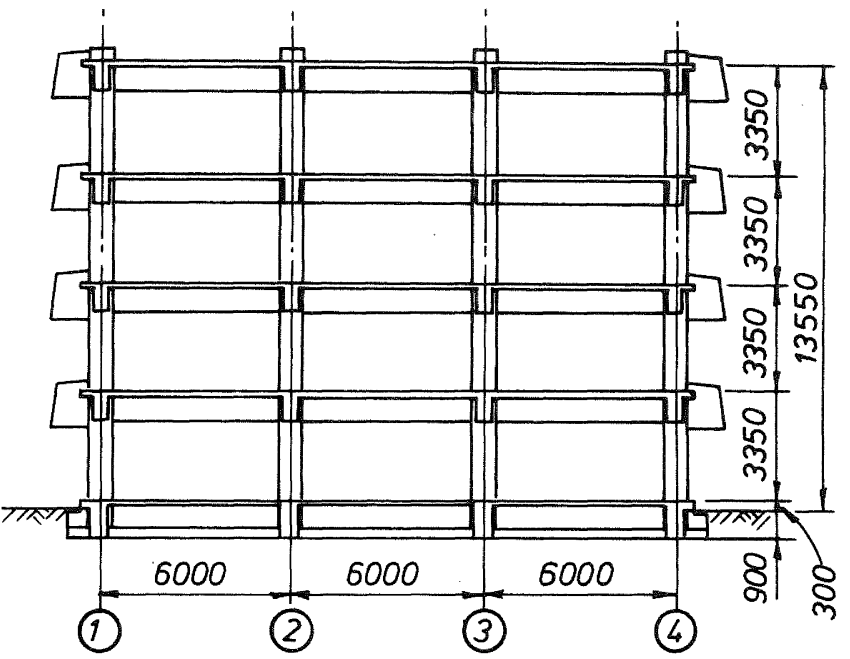

Note:- Roof floor was assumed to be same as other floors.

Figure 20 - Typical Section

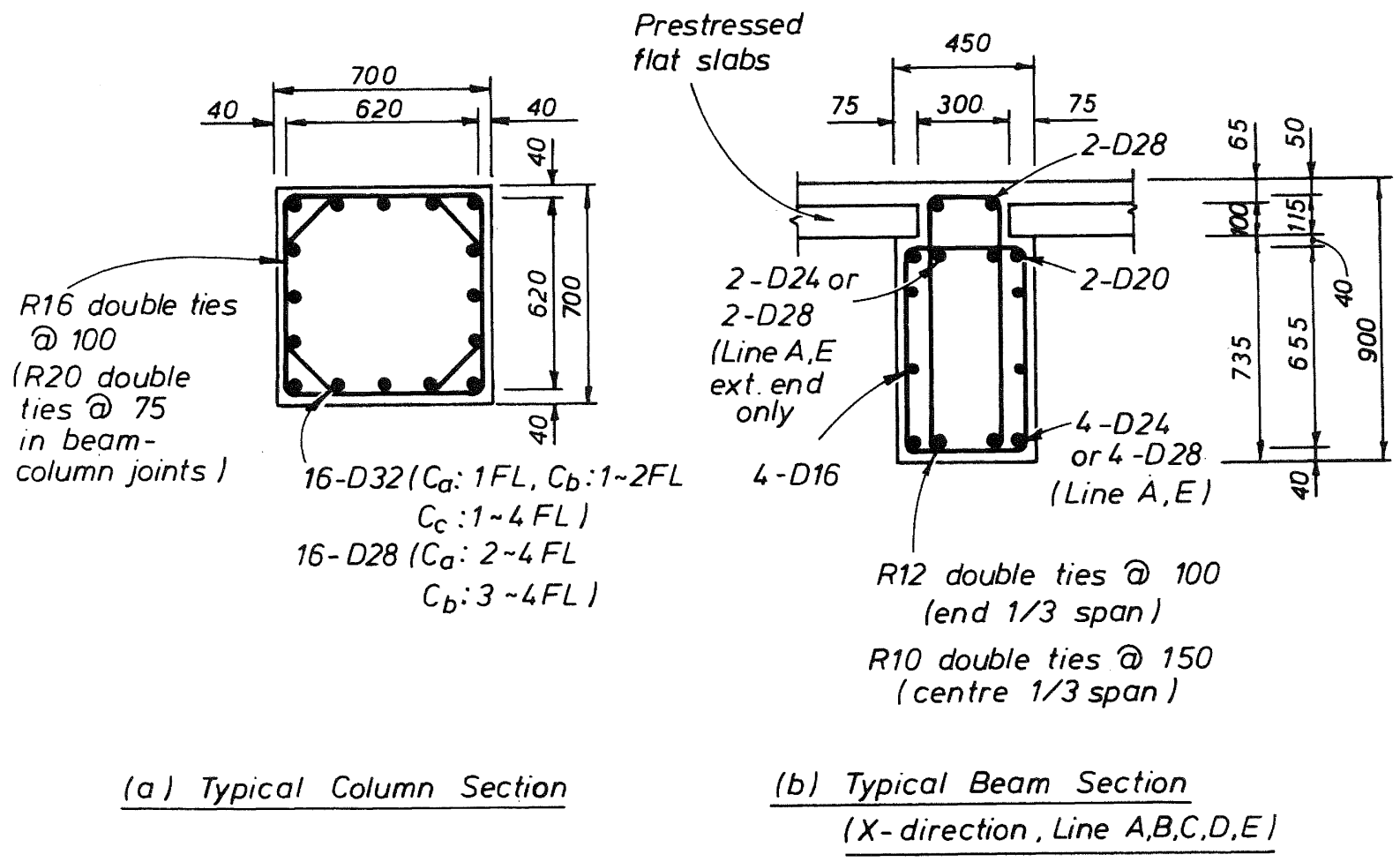


The third level procedure requires, in addition to all informations used in the second level procedure, the evaluation of the flexural and shear strengths of beams. In the case of this example all beams had ample shear strength to ensure flexural yielding, as beams of a ductile frame should. The effect of vertical load on the beams should be taken into account, but it was ignored here because it usually cancels out at interior joints and also at both ends of exterior spans. The effect of earthquake induced axial loads on column capacities was also ignored, expecting a similar cancellation of the effect.

Fig. 22 summarizes the yield moments at critical sections and the associated nodal moments, and Fig. 23 shows a simplified limit analysis to obtain the moment and shear distribution at the formation of the complete mechanism. From this, the third level procedure as summarized in Table 9 was obtained. As all columns would develop plastic hinges at ground floor level, and some at the top of the fourth storey, the mode shape would be very close to a straight line during the entire history of the response. Hence Eq. (6) was used in calculating the storey index $\phi$ for basic seismic index with Eq. (15). In the case of this building, the use of Eq. (6) instead of Eq. (7) results in $20 \%$ increase in the value of the storey index $\phi$.

As seen in Table 9, the third level procedure produced even higher seismic index in the first storey than the second level procedure, indicating that the second level procedure was in fact conservative. Formation of beam yield hinges reduced the column shear force to between 53 and $72 \%$ of those in the second level procedure. This reduced the total storey strength by $38 \%$. However great improvement in the ductility index outweighed this strength reduction considerably.

The seismic indices in the second and third storeys reduced as the procedure progressed from the second level to that at the third level. This is largely due to the loss of strength as the collapse mode changed from column hinge to beam hinge mechanisms. The "Standard" of Japan presently lacks quantitative provisions to evaluate the energy dissipating capacity of beam hinges. Instead it assigns the ductility index $F=3.0$ to all columns governed by beam hinges. This was a reasoned decision, as it was felt in the course of development of the "Standard". that beam hinge mechanism would not be prevalent in the existing Japanese buildings. Therefore any complication which might arise in the evaluation of beam ductility was avoided. It will be necessary to employ a quantitative ductility evaluation process for beams such as occur in this example.

In any case the seismic capacity of this example building is remarkably high. Compared with the protection index given in Table 4, the seismic indices in Table 9 are more than sufficient for the strongest conceivable earthquake. This can be also seen from the strength of the building in terms of yield storey shear coefficient shown in Table 9, under the heading marked $C$. Owing to the approximate evaluation shown in Fig. 23, the values in Table 9 are subject to fluctuations among storeys. Nevertheless it is believed that, even if the frame strength at beam yield would be evaluated more accurately by incremental nonlinear frame analysis or by exact limit analysis, the base shear coefficient would probably exceed 0.5 .

\section{CONCLUSIONS}

The Japanese "Standard" method of seismic capacity evaluation of existing reinforced concrete buildings, consisting of three-levels of procedures, was introduced. Details of this evaluation method were developed in such a way as to specifically suit Japanese low-rise reinforced concrete buildings. Direct application may not suit buildings of other countries. However, some of the general features such as those listed below, may be applicable to any evaluation procedure.

(1) The seismic capacity of existing buildings may be evaluated by means of the assessment of both strength and deformation capacities. This can be expressed by a product of two indices representing strength and deformability.

(2) The capacity of each storey of a multistorey building may be compared by relating it to the capacity of a single-degree-of-freedom system.

(3) For a structure consisting of vertical elements with different abilities to deform, rules to combine deformations need to be established. The Japanese "Standard" adopted two rules. One requires a linear combination of deformations. This is suitable for the evaluation of the seismic capacity at the failure of the most brittle, i.e. least ductile, element. The other rule specifies an elliptic combination and this attempts to evaluate the seismic capacity of the system at the failure of the most ductile element.

(4) A procedure consisting of several levels of sophistication is desirable when the "screening" of a large number of existing buildings is to be undertaken.

(5) As the first or preliminary level of evaluation, the concept of wall area ratio may be conveniently used.

(6) For an evaluation method to be effective and meaningful, a protection index, compatible with the evaluation method, is necessary. The proposal of protection index for the Japanese "Standard" was introduced.

The Japanese method was applied to a hypothetical New Zealand frame building, mainly to illustrate the numerical procedure. It was shown that a frame failing by beam 
TABLE 7 : FLEXURAL AND SHEAR STRENGTHS AND DUCTILITY FACTORS OF COLUMNS

\begin{tabular}{|c|c|c|c|c|c|}
\hline & & Unit & $\mathrm{C}_{\mathrm{a}}$ & $c_{b}$ & $c_{c}$ \\
\hline \multirow{3}{*}{ 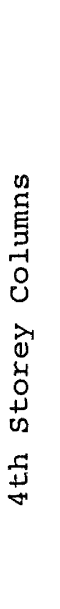 } & $\begin{array}{l}\text { Tension reinforcement } \\
0.8 \mathrm{~A} \mathrm{f}_{\mathrm{y}} \mathrm{h} \\
0.5 \mathrm{Ph}\left(\mathrm{I}_{-} \mathrm{P} / \mathrm{bh} \mathrm{f}_{\mathrm{c}}^{\prime}\right) \\
\mathrm{M}_{\mathrm{u}} \\
\mathrm{v}_{\mathrm{u}}\end{array}$ & $\begin{array}{l}\mathrm{kNm} \\
\mathrm{kNm} \\
\mathrm{kNm} \\
\mathrm{kN}\end{array}$ & $\begin{array}{l}5-D 28 \\
604 \\
44 \\
648 \\
529\end{array}$ & $\begin{array}{c}5-D 28 \\
604 \\
74 \\
678 \\
553\end{array}$ & $\begin{array}{c}5-D 32 \\
788 \\
121 \\
909 \\
742\end{array}$ \\
\hline & 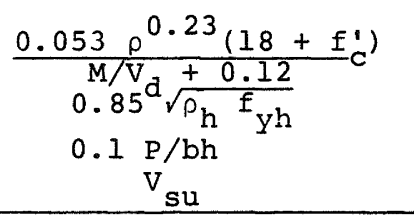 & $\begin{array}{r}\mathrm{MPa} \\
\mathrm{MPa} \\
\mathrm{MPa} \\
\mathrm{kN}\end{array}$ & $\begin{array}{l}0.900^{(2)} \\
1.579^{(3)} \\
0.026 \\
.982\end{array}$ & $\begin{array}{r}0.900 \\
1.579 \\
0.044 \\
989\end{array}$ & $\begin{array}{r}0.957 \\
1.579 \\
0.073 \\
1000\end{array}$ \\
\hline & $\begin{array}{l}\mu_{0} \\
k_{2} \\
\mu\end{array}$ & $\begin{array}{l}- \\
- \\
-\end{array}$ & $\begin{array}{l}8.56 \\
0 \\
5.00^{(4)}\end{array}$ & $\begin{array}{c}7.88 \\
0 \\
5.00\end{array}$ & $\begin{array}{c}3.48 \\
0 \\
3.48\end{array}$ \\
\hline \multirow{3}{*}{ 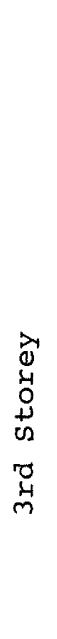 } & $\begin{array}{l}\text { Tension reinforcement } \\
0.8 \mathrm{~A}_{\mathrm{S}} \mathrm{f}_{\mathrm{Y}} \mathrm{h} \\
0.5 \mathrm{Ph}\left(\mathrm{I}-\mathrm{P} / \mathrm{bh} \mathrm{f}_{\mathrm{C}}^{\prime}\right) \\
\mathrm{M}_{\mathrm{u}} \\
\mathrm{V}_{\mathrm{u}}\end{array}$ & $\begin{array}{r}\mathrm{kNm} \\
\mathrm{kNm} \\
\mathrm{kNm} \\
\mathrm{kN}\end{array}$ & $\begin{array}{r}5-D 28 \\
604 \\
87 \\
691 \\
564\end{array}$ & $\begin{array}{r}5-D 28 \\
604 \\
144 \\
748 \\
611\end{array}$ & $\begin{array}{r}5-D 32 \\
788 \\
234 \\
1022 \\
834\end{array}$ \\
\hline & $\begin{array}{c}\frac{0.053 \rho^{0.23}\left(18+f_{c}^{\prime}\right)}{M / V_{d}+0.12} \\
0.85 \sqrt{\rho_{h} f_{y h}} \\
0.1 \mathrm{P} / \mathrm{bh} \\
\mathrm{V}_{\mathrm{su}}\end{array}$ & $\begin{array}{r}\mathrm{MPa} \\
\mathrm{MPa} \\
\mathrm{MPa} \\
\mathrm{kN}\end{array}$ & $\begin{array}{r}0.900 \\
1.579 \\
0.052 \\
992\end{array}$ & $\begin{array}{r}0.900 \\
1.579 \\
0.088 \\
1006\end{array}$ & $\begin{array}{r}0.957 \\
1.579 \\
0.147 \\
1052\end{array}$ \\
\hline & $\begin{array}{l}\mu_{0} \\
k_{2} \\
\mu\end{array}$ & $\begin{array}{l}- \\
\text { - } \\
=\end{array}$ & $\begin{array}{c}7.59 \\
0 \\
5.00\end{array}$ & $\begin{array}{c}6.46 \\
0 \\
5.00\end{array}$ & $\begin{array}{l}2.61 \\
0.19 \\
2.42\end{array}$ \\
\hline
\end{tabular}
(1) $\mathrm{v}_{\mathrm{u}}=2 \mathrm{M}_{\mathrm{u}} / l_{\mathrm{C}^{\prime}} \ell_{\mathrm{c}}=2.45 \mathrm{~m}$
(2) $\rho=0.912(5-D 28) 0.698(5-D 32) ; M / V d=\ell_{C} / 2 d=1.94$
(3) $\rho_{h}=4 \times 201 / 700 \times 100=0.0115<0.012$
(4) $\mu=\mu_{0}-k_{1}-k_{2} ; k_{1}=0 ; k_{2}=30\left(v_{u} / f_{c}^{\prime}-0.1\right) \geqq 0 ; k \mu$ 
TABLE 7A : FLEXURAL AND SHEAR STRENGTH AND DUCTILITY FACTORS OF COLUMNS

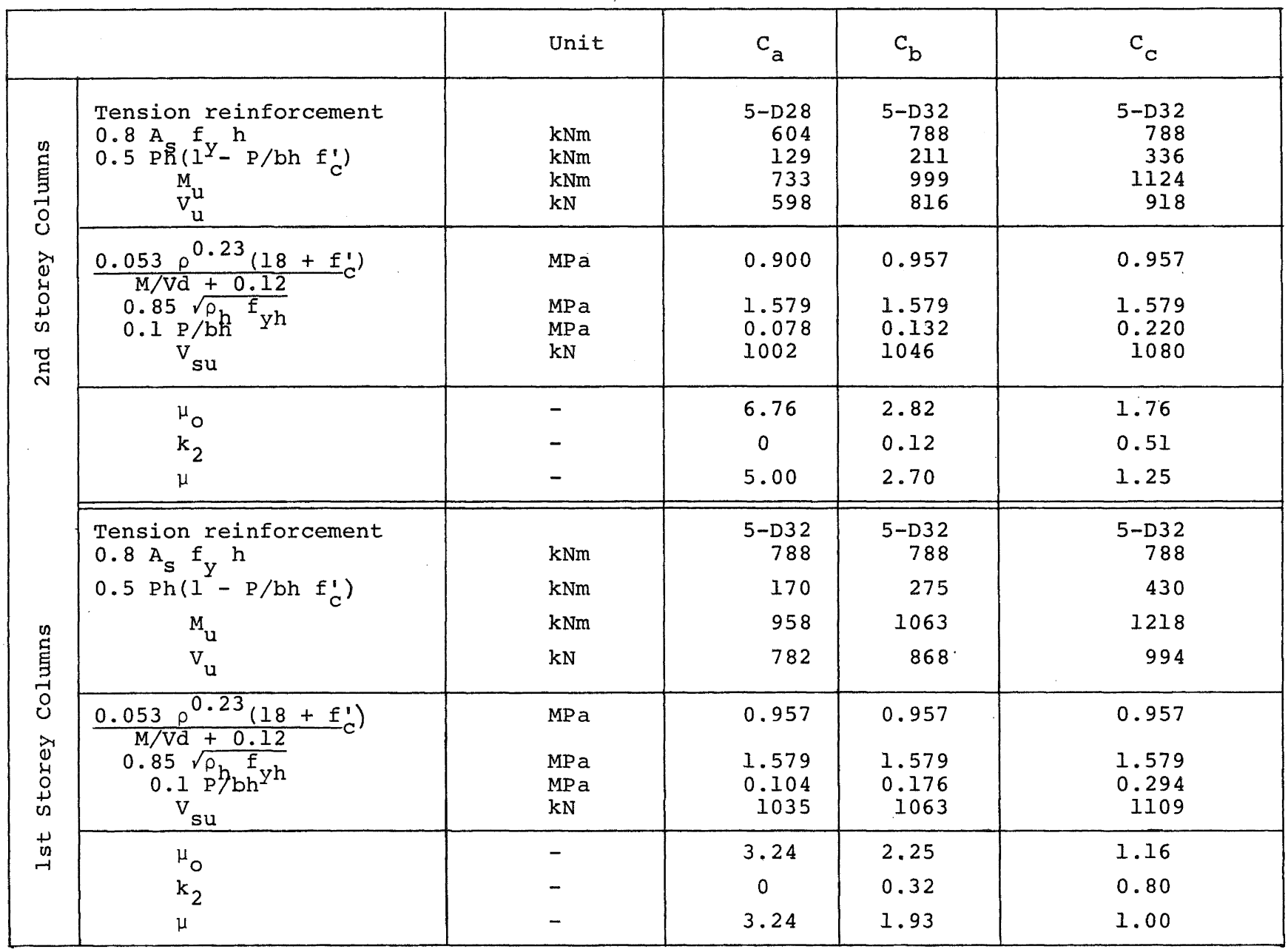

TABLE 8 SUMMARY OF THE SECOND LEVEL PROCEDURE

\begin{tabular}{|c|c|c|c|c|c|c|c|c|}
\hline Direction & Storey & Type & C & $\mathrm{F}$ & $E_{0}$ & $s_{\mathrm{d}}$ & $\mathrm{T}$ & $I_{s}$ \\
\hline \multirow{4}{*}{$X, Y$} & 4 & $\begin{array}{l}\text { FL.COL } \\
\text { FL.COL }\end{array}$ & $\begin{array}{l}0.92 \\
1.59\end{array}$ & $(3.20)^{2.99}(1)$ & 4.35 & 1.0 & 1.0 & 4.35 \\
\hline & 3 & $\begin{array}{l}\text { FL. COL } \\
\text { FL.COL }\end{array}$ & $\begin{array}{l}0.52 \\
0.87 \\
\end{array}$ & $\begin{array}{r}2.33(1) \\
(3.20)(1) \\
\end{array}$ & 2.31 & 1.0 & 1.0 & 2.31 \\
\hline & 2 & $\begin{array}{l}\text { FL.COL } \\
\text { EL.COL } \\
\text { FL.COL }\end{array}$ & $\begin{array}{l}0.38 \\
0.56 \\
0.17\end{array}$ & $\begin{array}{c}1.54 \\
2.46 \\
(3.20)\end{array}$ & 1.57 & 1.0 & 1.0 & 1.57 \\
\hline & 1 & $\begin{array}{l}\text { FL.COL } \\
\text { FL.COL } \\
\text { FL.COL }\end{array}$ & $\begin{array}{l}0.31 \\
0.45 \\
0.16\end{array}$ & $\begin{array}{c}1.27 \\
2.06 \\
(2.69)\end{array}$ & 1.32 & 1.0 & 1.0 & 1.32 \\
\hline
\end{tabular}

(1) $E_{0}$ was determined by $\phi\left(c_{1}+c_{2}\right) F_{1}$

(2) $E_{0}$ was determined by $\phi \sqrt{\mathrm{C}_{1}{ }^{2} \mathrm{~F}_{1}{ }^{2}+\left(\mathrm{C}_{2}+\mathrm{C}_{3}\right)^{2} \mathrm{~F}_{2}{ }^{2}}$ 


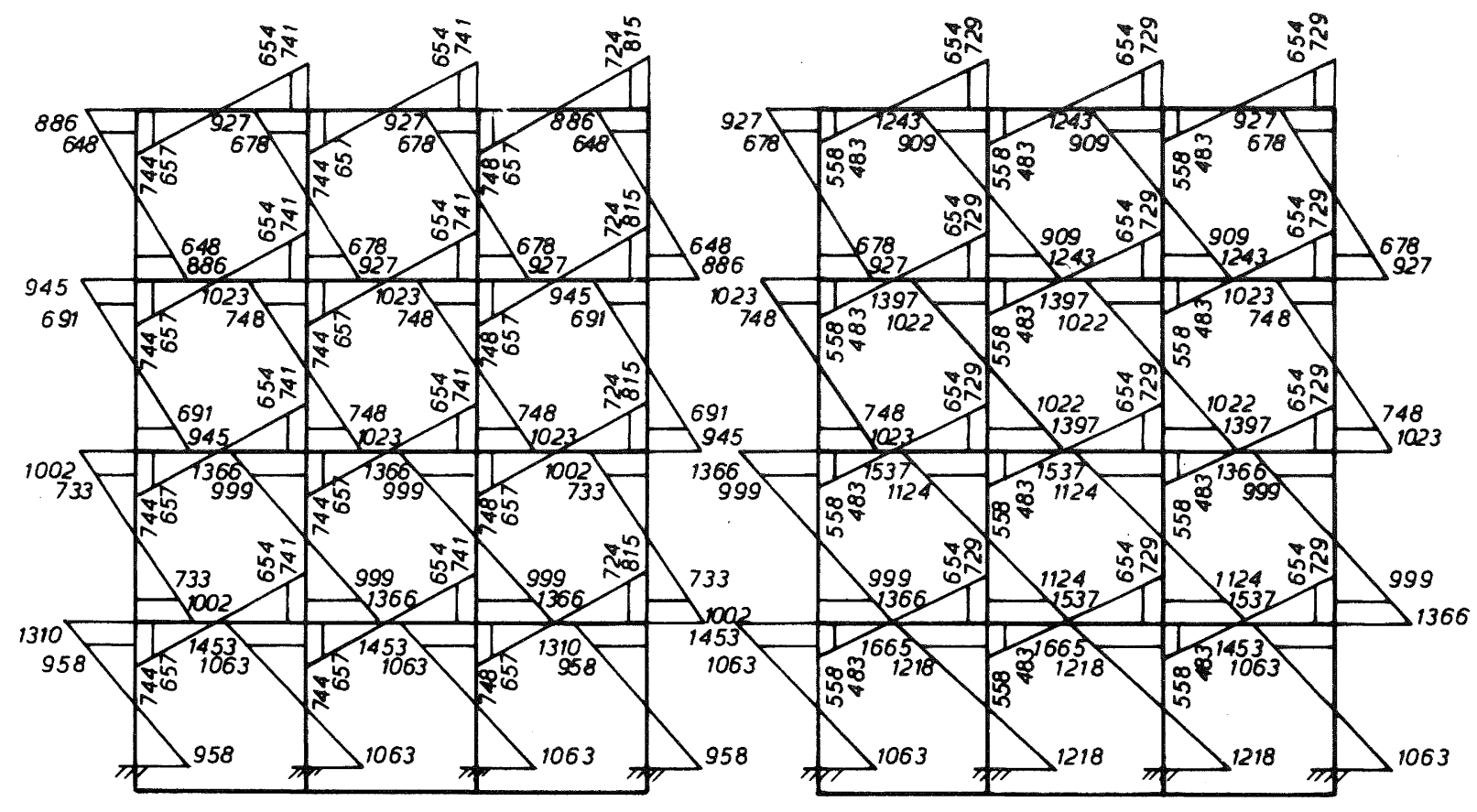

(a) FRAME LINE A\&E

(b) FRAME LINE B,C,D

Figure 22 - Yield Moment at Critical Sections and Nodal Moments

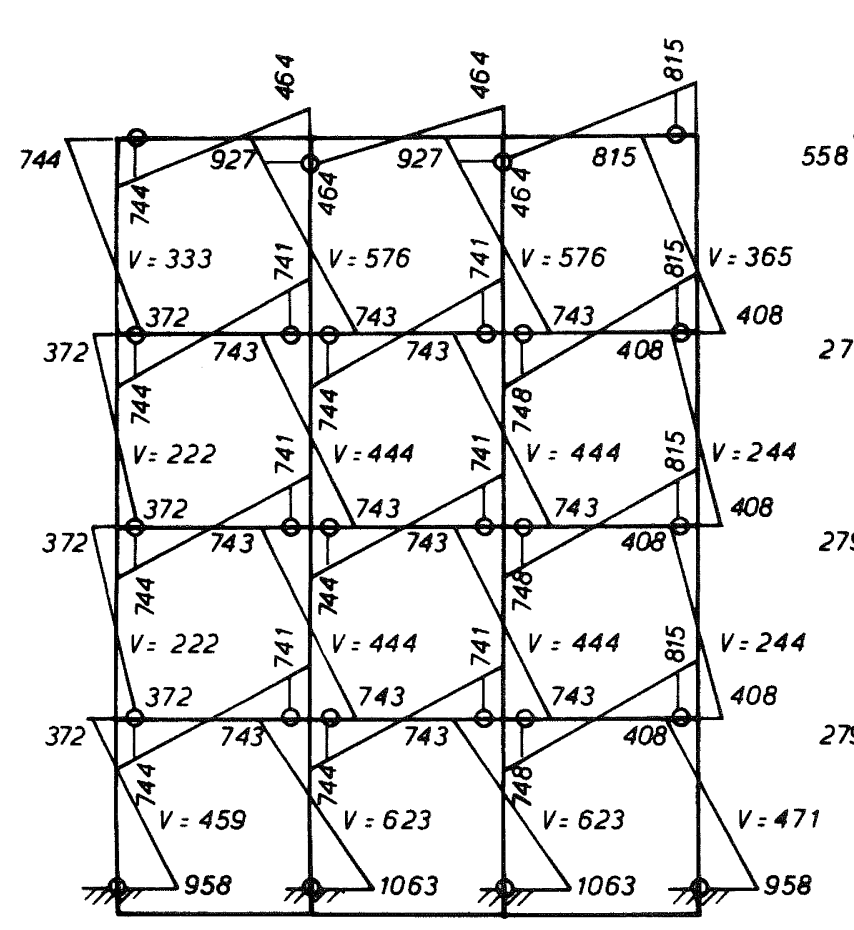

(a) FRAME LINE A\&E

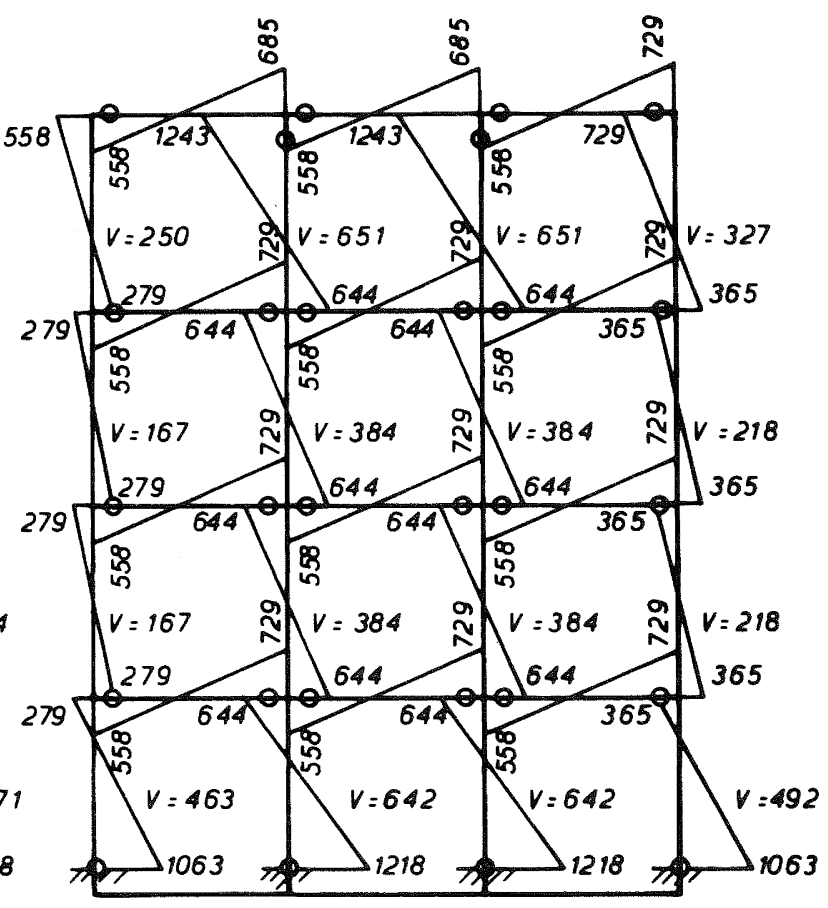

(b) FRAME LINE B,C,D 
TABLE 9 : SUMMARY OF THE THIRD LEVEL PROCEDURE

\begin{tabular}{|c|c|c|c|c|c|c|c|c|}
\hline \multirow[t]{2}{*}{ Direction } & Storey & Type & C & $\mathrm{F}$ & $E_{0}$ & $S_{D}$ & $\mathrm{~T}$ & $I_{s}$ \\
\hline & 4 & $\begin{array}{l}\text { BM-BM } \\
C L-B M\end{array}$ & $\begin{array}{l}0.65 \\
1.29\end{array}$ & $\begin{array}{r}3.00 \\
3.001\end{array}$ & 4.36 & 1.0 & 1.0 & 4.36 \\
\hline & 3 & $\mathrm{BM}-\mathrm{BM}$ & 0.64 & 3.00 & 1.65 & 1.0 & 1.0 & 1.65 \\
\hline & 2 & BM-BM & 0.43 & 3.00 & 1.28 & 1.0 & 1.0 & 1.28 \\
\hline & 1 & $\mathrm{BM}-\mathrm{CL}$ & 0.57 & $3.00^{1}$ & 2.07 & 1.0 & 1.0 & 2.07 \\
\hline
\end{tabular}

(1) The ductility index is determined from the smaller value with respect to the top or the bottom of the column. The $F$ value corresponding to column yield was 3.20 for all column hinges, hence $F=3.0$, appropriate for flexural beams was used.

yielding should be evaluated by a procedure which explicitly considers the strength and deformation of beams. The assumption of infinitely strong floor system resulted in a conservative evaluation.

For a well conceived frame building, designed in accordance with the current New Zealand building code, there will be no need for seismic capacity evaluations of any kind. However, for existing buildings, particularly older ones, some kind of evaluation method would need to be worked out. As in Japan this should consider the actual features of existing buildings in the country. The Japanese method was developed specifically with the aim at Japanese buildings. Typically these contain shear walls in abundance and other miscellaneous concrete walls, as well as short columns likely to fail either in shear or in flexure at both ends. The author did not have an opportunity to analyze in depth existing New Zealand buildings. No further suggestion for a possible method of evaluation can be offered.

It might be worthwhile, however, to point out that the order of emphasis in the Japanese evaluation method, with the primary emphasis placed on columns and walls, a secondary emphasis on beams, and with none on beam-column connections, is in accordance with the severity in the consequence of the failure of each part observed in Japan. Failure of columns and walls might lead to a complete collapse, while the failure of beams may be local and is usually repairable. The failure of beam-column connections is yet to be identified in the field. Although experience with laboratory experiments strongly suggests the significance of beam-column joints in the design of new buildings, such connections are least likely to be the cause for concern in existing buildings because the proportioning and detailing of beams and columns in older buildings are likely to be inferior to those used in modern designs.

\section{APPENDIX : CALCULATION OF MEMBER STRENGTH}

Summarized here are the equations for flexural and shear. strengths of rectangular columns, columns with side walls, walls with or without boundary elements, and beams, contained in the "Standard for Seismic Capacity Evaluation"(7). Most of these had been developed empirically based on Japanese test data. However, some equations were formulated in the course of the development of the "Standard", and therefore they are tentative.

\section{Al. Material Strengths}

The compressive strength of concrete $f$ ' may be taken equal to the specified strength used in the structural design. The yield strength $f$ of plain bars may be taken 300 MPa, and that of deformed bars may be taken equal to specified minimum yield point plus $50 \mathrm{MPa}$.

Where more accurate information is available, appropriate values may be taken therefrom.

A2. Flexural Strength of the Rectangular Columins

$$
\text { For } \begin{aligned}
\mathrm{P}_{\max } & \geqq P>0.4 \mathrm{bh} \mathrm{f}_{\mathrm{C}}^{\prime} \\
\mathrm{M}_{\mathrm{u}}= & \left(0.8 \mathrm{~A}_{\mathrm{S}} \mathrm{f}_{\mathrm{y}} \mathrm{h}+0.12 \mathrm{bh}^{2} \mathrm{f}_{\mathrm{c}}^{\prime}\right) \mathrm{x} \\
& \frac{\mathrm{P}_{\max }-\mathrm{P}}{\mathrm{P}_{\max }-0.4 \mathrm{bh} \mathrm{f}_{\mathrm{C}}^{\prime}}
\end{aligned}
$$

For 0.4 bh $f_{C}^{\prime} \geqq P \geqq 0$

$$
M_{u}=0.8 A_{s} f_{y} h+0.5 P h\left(I-P / b h f_{C}^{\prime}\right)
$$

For $0 \geqq P>P_{\text {min }}$

$$
M_{u}=0.8 A_{s} f_{y} h+0.4 P h
$$

where

$A_{S}=$ area of tensile reinforcement $\left(\mathrm{mm}^{2}\right)$

$\mathrm{b}=$ width of section (mm)

$f_{C}^{\prime}=$ compressive strength of concrete (MPa)

$\mathrm{f}_{\mathrm{y}}=$ yield strength of longitudinal

$\mathrm{h}=$ depth of section (mm) 
$\mathrm{M}_{\mathrm{u}}=$ flexural strength (N.mm)

$P$ = axial force on the section (N)

$P_{\text {max }}=b h f_{C}^{\prime}+\sum A_{S} f_{y}(N)$

$P_{\text {min }}=\sum A_{S} f_{y}(N)$

A3. Flexural Strength of Columns with Side Walls

A side wall in tension side shall be neglected. Hence if there is no side wall on the compression side, Eq. (A-I) is applicable. For the sections with a side wall in compression, with reference to $\mathrm{Fig}$. (Al-a) the following equations are applicable.

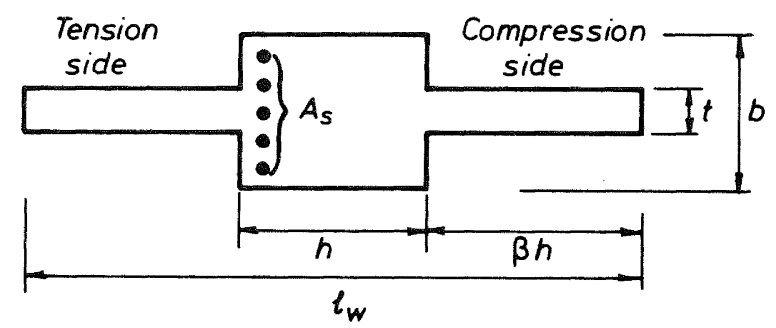

(a) Column with side walls

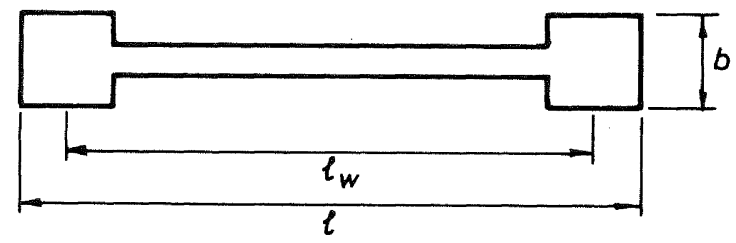

(b) Wall with two boundary columns

Figure A-1 : Notations for Members

$$
\text { For } \begin{aligned}
P \leq & \left\{0.5 \alpha_{e}(0.9+\beta)-13 \rho\right\} b h f_{C}^{\prime} \\
M_{u}= & (0.9+\beta) A_{S} f_{Y} h+0.5 \mathrm{Ph} \\
& \left\{1+2 \beta-\frac{P}{\alpha_{e} b h f_{C}^{\prime} \times}\right. \\
& \left.\left(1+\frac{A_{S} f_{Y}}{P}\right)^{2}\right\}
\end{aligned}
$$

For $P>\left\{0.5 \alpha_{e}(0.9+\beta)-13 \rho\right\}$ bh $f_{c}^{\prime}$ substitute this value for $P$ in $\mathrm{Eq}$. $(\mathrm{A}-2)$

where total cross-sectional area of wall-column assemblage

$$
\begin{aligned}
& \alpha_{e}=\frac{b l_{w}}{b a l+c o l u m n} \\
& \text { length of sidew wall on compression } \\
& \beta=\text { side } h \\
& \rho=\frac{{ }^{A} S}{b h} \\
& A_{S}=\text { area of tensile reinforcement } \\
& \text { (see Fig. Al-a) } \\
& \mathrm{b}=\text { width of column section (mm) } \\
& \mathrm{h}=\text { depth of column section (mm) } \\
& l_{w}=\text { out-to-out distance of wall-column }
\end{aligned}
$$

For other notations see Eq. (A1-1)

A4. Flexural strength of a wall with Two Boundary Columns

When a wall has more than two columns, the area of main bars in the intermediate columns shall be added to the area of vertical wall reinforcement.

$M_{u}=A_{S} f_{y} l_{w}+0.5 A_{S W} f_{y w} l_{w}+0.5 \mathrm{P}_{w}$

where

$A_{S}=$ total area of longitudinal reinforce $\overline{2}$

$A_{\text {SW }}=$ total area of vertical reinforcement in wall excluding the reinforcement in the boundary columns $\left(\mathrm{mm}^{2}\right)$

$f_{y}=y$ ield strength of longitudinal reinforcement in column (MPa)

$\mathrm{f}_{\mathrm{yw}}=$ yield strength of vertical reinforcement in wall (MPa)

$\ell_{w}=$ distance between centroids of boundary columns (mm)

A5. Flexural Strength of Walls with One or no Boundary Column

Equations $(A-1),(A-2)$ or $(A-3)$ may be adopted with appropriate modifications, depending on the shape of and bar arrangement in the wall.

A6. Flexural Strength of Beams with or without Spandrel Walls

Equations $(A-1),(A-2)$ or $(A-3)$ may be used, by equating the axial force $P$ to zero. For rectangular beams, the following equations may be used. The effects of a monolithic slab and those of intermediate bars, in case of beams with more than two layers of longitudinal reinforcement, may be taken into account.

$M_{u}=0.9 A_{s} f_{y} d$

where

$A_{S}=$ area of tensile reinforcement $\left(\mathrm{mm}^{2}\right)$

$\mathrm{d}=$ distance from the compressive face to the centroid of tensile reinforcement (mm).

\section{A7. Shear Strength of Rectangular Columns}

The following is an empirical equation derived by Arakawa for beams. It was subsequently modified to include the effect of axial load, as follows:

$$
\begin{aligned}
V_{s u}= & \left\{\frac{0.053 \rho^{0.23\left(18+f_{c}^{\prime}\right)}}{M / V d+0.12}+0.85 \sqrt{\rho_{h} f_{y h}}\right. \\
& \left.+\frac{0.1 P}{b h}\right\}(0.8 \mathrm{bh})
\end{aligned}
$$

where

$$
\begin{aligned}
\rho= & 100 \mathrm{~A} / \mathrm{bd} \\
\rho_{\mathrm{h}}= & \text { transverse shear reinforcement } \\
& \text { ratio; if } \rho \mathrm{h} \text { exceeds } 0.012, \\
& \text { substitute } \rho_{\mathrm{h}}=0.012
\end{aligned}
$$


$A_{S}=$ area of tensile reinforcement $\left(\mathrm{mm}^{2}\right)$

b - width of section (mm)

$\mathrm{d}=$ distance from the compressive face to the centroid of tensile reinforcement (mm)

$f_{C}^{\prime}=$ compressive strength of concrete (MPa)

$E_{y h}=$ yield strength of transverse shear reinforcement ( $\mathrm{MPa})$

$\mathrm{h}=$ depth of section (mm)

$M / V=$ shear span ( $m$ m); in case of columns this may be taken as one half of the clear height. M/Vd must not be taken less than, nor more than 3

$\mathrm{P}=$ axial force on the section $(\mathrm{N})$; if $\mathrm{P} / \mathrm{bh}$ exceeds 8 (MPa), substitute $\mathrm{P} / \mathrm{bh}=8$

$\mathrm{V}_{\mathrm{su}}=$ shear strength $(\mathrm{N})$

A8. Shear Strength of Column with Side Walls

$V_{\text {su }}=0.25 \sqrt{f_{C}^{T}}\left(l_{w} / l_{c}\right) A+0.5 \rho_{h} f_{y h} b h$

$$
+0.5 \rho_{w} f_{y w} t\left(l_{w}-h\right)+0.1 p
$$

where

$\rho_{h}=$ transverse reinforcement ratio for the column

$\rho_{\mathrm{w}}=$ lateral reinforcement ratio for the walls

$A=$ total cross sectional area of wallcolumn assembly $\left(\mathrm{mm}^{2}\right)$

$\mathrm{b}=$ width of column section (mm)

$f_{C}^{\prime}=$ compressive strength of concrete (MPa)

$\mathrm{f}_{\mathrm{yh}}=$ yield strength of column transverse reinforcement (MPa)

$f_{y w}=y i e l d$ strength of wall lateral reinforcement (MPa)

$\mathrm{h}=$ depth of column section (mm)

$\ell_{C}=$ clear height of column (mm)

$\ell_{w}=$ out-to-out distance of wall-column assemblage (mm)

$t=$ thickness of wall (mm)

A9 Shear Strength of Walls with Two Boundary Columns

Equation $(A-5)$ is modified as follows:

$$
\begin{aligned}
v_{\text {su }}= & \frac{\left\{0.53 \rho_{e} 0.23\left(18+f_{c}^{\prime}\right)\right.}{2 h_{w} / l+0.12}+ \\
& \left.0.85 \sqrt{\rho_{w} f_{y w}}+\frac{0.1 p}{b_{e} l}\right\}_{e} l_{w}
\end{aligned}
$$

where

$$
\begin{aligned}
& \rho_{e}=100 \mathrm{~A}_{\mathrm{s}} / \mathrm{b}_{\mathrm{e}}{ }^{l} \\
& \rho_{\mathrm{w}}=\underset{\substack{\text { equivalent } \\
\text { ratio }}}{ } \text { wall reinforcement }
\end{aligned}
$$

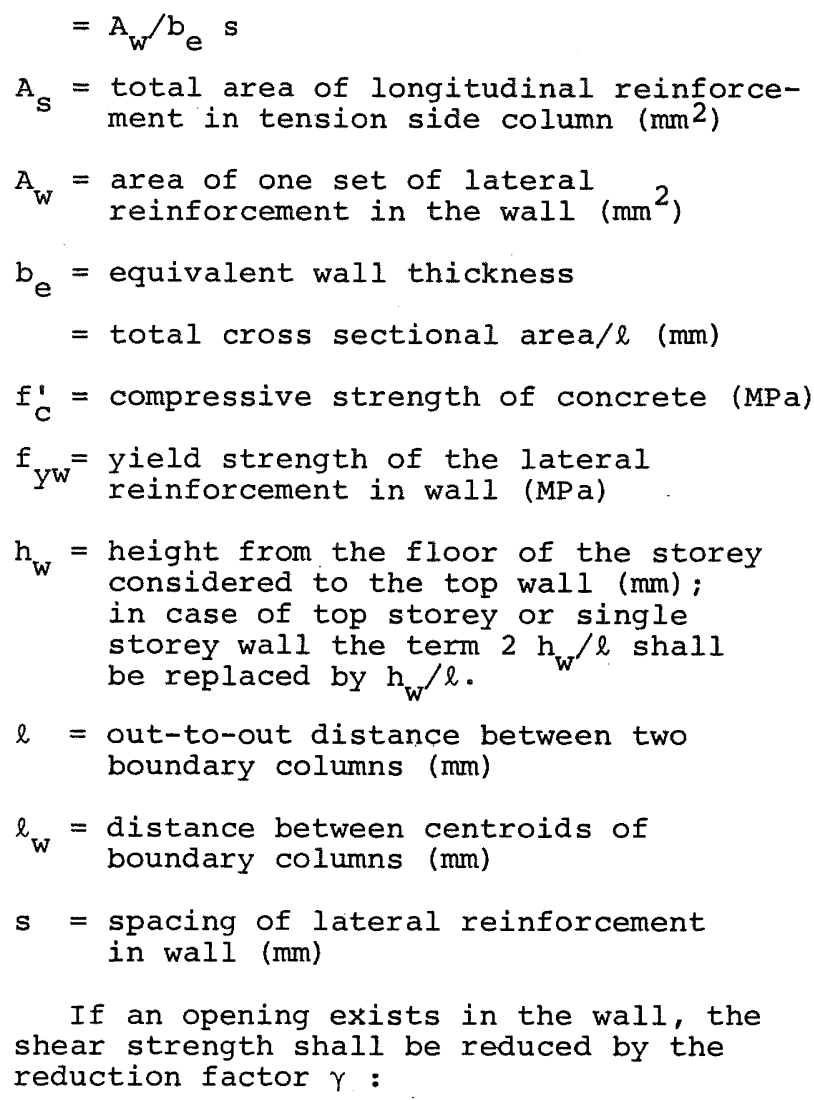

If an opening exists in the wall, the shear strength shall be reduced by the reduction factor $\gamma$ :

$\gamma=1-\sqrt{\frac{\text { vertical area of opening }}{h_{s} l_{w}}}$

where

$h_{S}=$ storey height

Equation (A-8) is applicable when the value of $\gamma$ is greater than 0.6 . If the opening is large so as to make the value of reduction factor less than 0.6 , the wall should be treated as an equivalent frame.

\section{Al0. Shear Strength of Walls with One} or No Boundary Column

Equations $(A-5),(A-6)$ or $(A-7)$ may be adopted with appropriate modifications, depending on the shape of and bar arrangement in the wall.

\section{All. Shear Strength of Beams with or without Spandrel Walls}

Equations $(A-5),(A-6)$ or $(A-7)$ may be used, after taking the axial force $P$ as equal to zero.

\section{ACKNOWLEDGEMENTS}

This paper was prepared in 1980 while the author was a visiting professor in the Department of Civil Engineering of the University of Canterbury, Christchurch, New Zealand. The stay was made possible by financial support from the University of Canterbury, the Ministry of Works and Development of New Zealand, and the University of Tokyo, Japan. 
The preparation of the paper was stimulated by discussions with several members of the Department of Civil Engineering in the University of Canterbury particularly with Professor R. Park, the Head of the Department of Civil Engineering, and with Professor T. Paulay, to whom the author is also indebted for his critical reading of the manuscripts.

The late Mr O.A. Glogau, former Chief Structural Engineer of the Ministry of Works and Development, offered numerous suggestions and gave warm encouragement to the author.

Messrs G.H.F. McKenzie and B.W. Buchanan of the Ministry of Works and Development provided technical data for prototype buildings in New Zealand.

Drs M. Hirosawa and T. Kubo of the Building Research Institute, Ministry of Construction of Japan, furnished through correspondence up to date information relevant to the revisions of the building code of Japan.

Mrs J.Y. Ward and Mrs D.E. Ball typed the manuscript in a minimum period of time.

Most of the drawings in this report were prepared by Mrs V. Grey.

The author expresses his most grateful appreciation to all who assisted him in this undertaking.

\section{REFERENCES}

1. Hirosawa, M., "Judgement of Seismic Resistance of Existing Reinforced Concrete Buildings - a BRI Proposal (in Japanese)", Kenchiku Gijutsu Journal, Nov. 1973.

2. "Evaluation and Strengthening of Earthquake Resistant Properties of Existing Reinforced Concrete School Buildings (in Japanese)", Architectural Institute of Japan, 1975.

3. Hirosawa, M., Higashi, Y., Ogura, K. and Kikusho, S., "An Evaluation Method of Earthquake Resistant Properties of Existing Reinforced Concrete School Buildings", Proc. US-Japan Cooperative Research Program in Earthquake Engineering with Emphasis on the Safety of School Buildings, Hawaii, 1975, pp. 174-187.

4. Okada, T. and Bresler, B., "Strength and Ductility Evaluation of Existing Low-Rise Reinforced Concrete Buildings - Screening Method", Report EERC 76-1, University of California, Berkeley, Feb. 1976 , $149 \mathrm{pp}$.

5. Shiga, T., Shibata, A. and Takahashi, T., "Earthquake Damage and Wall Index of Reinforced Concrete Buildings (in Japanese)", Proc. Tohoku District Symposium, Architectural Institute of Japan, No. 12, Dec. 1968, pp. 29-32.

6. Glogau, O.A., "Low Rise Reinforced Concrete Buildings of Limited
Ductility, Some Lessons from Recent Earthquake Damage" "Bull. NZNSEE, Vol. 13, No. 2, June 1980, pp. 182193

7. "Standard for Seismic Capacity Evaluation of Existing Reinforced Concrete Buildings (in Japanese)", Japan Association for Building Disaster Prevention, April 1977. $131 \mathrm{pp}$.

8. Aoyama, H. and Otani, S., "Recent Japanese Developments in Earthquake Resistant Design of Reinforced Concrete Buildings", presented during 1979 ACI Convention in Washington, D.C. at the Three Sessions to Celebrate C.P. Siess' Contributions to Research, Practice, and Education, Nov. 1979.

9. Okada, T., "Evaluation of Seismic Capacity of Reinforced Concrete Buildings (in Japanese)", Kenchikukai Journal, Vol. 26, No. 12, Dec. 1977.

10. Fukada, Y., "Study on the Restoring Force Characteristics of Reinforced Concrete Buildings (in Japanese)", Proc. Kanto District Symposium, Architectural Institute of Japan, No. 40, Nov. 1969, pp. 121-124.

11. Umemura, H., "Dynamic Earthquake Resistant Design for Reinforced Concrete Buildings (in Japanese)" , Giho-do Publishing Co., Tokyo, $1973,420 \mathrm{pp}$.

12. Hisano, M. and Okada, T., "Earthquake Response of Low-Rise Reinforced Concrete Buildings with Structural Walls (SDF Parallel Wall-Frame System) (in Japanese)", Trans. Annual Convention, Architectural Institute of Japan, Oct. 1975, pp. $481-482$.

13. Higashi, y. et al, "Synthetic Experimental Research on Improving Ductility of Reinforced Concrete Short Columns (in Japanese)", Concrete Journal, Vol. 13, No. 1, Jan. 1975, pp. 2-18.

14. Umemura, H., Okada, T. and Murakami, M., "Protection Index for the Seismic Capacity Evaluation Standard of Reinforced Concrete Buildings (in Japanese)" "Trans. Annual Convention, Architectural Institute of Japan, Oct. 1980, pp. 1537-1538.

15. Kawabata, S., Kamiya, Y. and Matsui, M., "Earthquake Countermeasures of Shizuoka Prefecture Primarily about Buildings", Proc. 7th World Conference on Earthquake Engineering (9/313), Istanbul, Turkey, Sept. 1980 .

16. Murakami, M. and Penzien, J., "Nonlinear Response Spectra for Probabilistic Seismic Design and Damage Assessment of Reinforced Concrete Structures", Report EERC 75-38, University of California at Berkeley, Nov. 1975 , pp 83 . 